\title{
Cladocera and Copepoda (Crustacea: Branchiopoda) of the Lake Bolon and its basin (Far East of Russia)
}

\section{Cladocera и Copepoda (Crustacea) озера Болонь и его бассейна (Аальний Восток Российской Федераџии)}

\author{
Petr G. Garibian ${ }^{1}$, Elena S. Chertoprud ${ }^{1,2}$, Artem Yu. Sinev ${ }^{1,3}$, \\ Nikolai M. Korovchinsky ${ }^{1}$, Alexey A. Kotov ${ }^{1^{*}}$ \\ П.Г. Гарибян ${ }^{1}$, Е.С. ЧертопруА ${ }^{1,2}$, А.Ю. Синев ${ }^{1,3}$, \\ Н.М. Коровчинский ${ }^{1}$, А.А. Котов ${ }^{{ }^{*}}$
}

\footnotetext{
${ }^{1}$ A.N. Severtsov Institute of Ecology and Evolution, Leninsky Prospect 33, Moscow 119071, Russia.

${ }^{1}$ Институт проблем экологии и эволюции им. А.Н. Северцова РАН, Ленинский проспект, д. 33, Москва 119071, Россия.

2 Department of Hydrobiology, Biological Faculty, M.V. Lomonosov Moscow State University, Leninskie Gory, Moscow 119991, Russia.

2 Кафедра гидробиологии, Московский государственный университет им. М.В. Ломоносова, Ленинские горы, Москва 119991, Россия.

${ }^{3}$ Department of Invertebrate Zoology, Biological Faculty, M.V. Lomonosov Moscow State University, Leninskie Gory, Moscow 119991, Russia.

${ }^{3}$ Кафедра зоологии беспозвоночных, Московский государственный университет им. М.В. Ломоносова, Ленинские горы, Москва 119991, Россия.

*Corresponding author: alexey-a-kotov@yandex.ru
}

KEY WORDS: Crustacea, Cladocera, Copepoda, morphology, taxonomy, fauna, biodiversity.

КЛЮЧЕВЫЕ СЛОВА: Crustacea, Cladocera, Copepoda, морфология, систематика, фауна, биоразнообразие.

ABSTRACT. The microcrustacean fauna (Cladocera, Copepoda and Ostracoda) of continental water bodies in the southern portion of Russian Far East is studied inadequately relative to the European Part of the country. The aim of the present study is to make inventory of the Cladocera and Copepoda fauna of the Lake Bolon basin and evaluate the biogeographic status of microcrustaceans found there. In toto, 45 taxa of Cladocera (of which four taxa could be identified only to genus) and 13 taxa of Copepoda are found. For some taxa we provide short morphological descriptions and comments on their distribution ranges in Northern Eurasia. We subdivided all taxa into five main faunistic complexes. In general, fauna of Cladocera and Copepoda of the Lake Bolon Basin is diverse and specific, it includes endemics of the Far East. In the investigated region cladocerans are more speciose and heterogeneous in their range types relative to the copepods. But most part of revealed cladoceran and copepod taxa belong to an artificial "complex" of species which are widely distributed in Eurasia (or even in Holarctic), or regarded as "cosmopolitan". Each such taxon apparently needs an accurate taxonomic revision in the global scale keeping in mind Frey's non-cosmopolitanism paradigm. Only newly obtained adequate data could provide a basis for biogeographical analysis of the Cladocera and Copepoda of the Far East fauna as a whole.
How to cite this article: Garibian P.G., Chertoprud E.S., Sinev A.Yu., Korovchinsky N.M., Kotov A.A. 2019. Cladocera and Copepoda (Crustacea: Branchiopoda) of the Lake Bolon and its basin (Far East of Russia) // Arthropoda Selecta. Vol.28. No.1. P.37-63. doi: 10.15298/arthsel. 28.1.05

РЕЗЮМЕ. Фауна микроскопических ракообразных (Cladocera, Copepoda и Ostracoda) континентальных водоемов юга Дальнего Востока Российской Федерации исследована несравнимо хуже, чем фауна европейской части РФ. Цель данной работы - провести инвентаризацию фауны Cladocera и Copepoda озера Болонь и его бассейна и оценить биогеографический статус найденных видов. В общей сложности нами было найдено 45 таксонов Cladocera (среди них, определение четырех таксонов было возможно только до уровня рода) и 13 таксонов Copepoda. Для некоторых таксонов приведены морфологические описания и комментарии по поводу их распространения в Северной Евразии. Все найденные таконы отнесены к пяти основным фаунистическим комплексам. В общем, фауна Cladocera и Copepoda Озера Болонь и его бассейна разнообразна и специфична, она включает ряд эндемиков Дальнего Востока. Кладоцеры более разнообразны в этом регионе, чем копеподы по видовому составу и типу ареала. Однако большая часть 
кладоцер и копепод может быть отнесена к искусственному «комплексу» видов, широко распространенных в Евразии (или даже в Голарктике), или имеющих «космополитическое» распространение. Каждый такой таксон должен быть подвергнут аккуратной таксономической ревизии в масштабе мировой фауны, принимая во внимание концепцию «некосмополитизма» Дэвида Фрая. Именно такие данные должны стать базисом для биогеографического анализа Cladocera и Copepoda Дальнего Востока и мировой фауны в целом.

\section{Introduction}

The microcrustacean fauna (Cladocera, Copepoda and Ostracoda) of continental water bodies in the southern part of the Russian Far East is studied inadequately relative to the European part of the country [Kotov et $a l ., 2010]$, and even to more northern territories of the Far East [Streletskaya, 1975a, b]. Efforts to study the former were started from the largest water body, Lake Khanka [Rylov, 1933]. Its fauna remains the most explored among all water bodies of this region; the number of publications on it keeps steadily growing [Uéno, 1939, 1940; Markovtsev, 1979; Barabanshchikov, Kojevnikov, 1998; Barabanshchikov, 2000, 2004, etc.].

A series of large expeditions was organized to the Amur basin in the 1930's-1940's [Rylov, 1933]. As a result, the fishes of this region were intensively studied [Berg, 1948; Nikolsky, 1956], but special studies of the plankton began only in the second half of the 20th century. They were focused mainly on large lakes and basins of few large rivers [Borutsky, 1952a; Manujlova, 1964; Borutsky et al., 1991], mainly the Amur (= Hellong Jiang) River and its large affluent, the Ussuri River [Mikulich, 1948; Barabanshchikov, 2014].

Many examples of the Far Eastern fauna specificity were obtained to date, e.g. a series of specific East Asian taxa of species and subspecies rank was found there [Ueno, 1940; Borutsky, 1952a; Frey, 1973; Borutsky et al., 1991; Korovchinsky, 2000, 2009; Kotov et al., 2006; Korovchiunsky, 2009; Korovchinsky, Sheveleva, 2009; Smirnov, Sheveleva, 2010]. This fact stresses the relevance of faunistic and taxonomic investigations on the Far Eastern planktonic crustaceans. However, at present, only few territories of this large region are studied more or less satisfactorily, the existing literature is fragmentary and any publications on some large territories are almost (or totally) absent. The significance of such studies was demonstrated in a series of publications on the Zeya River basin [Kotov et al., 2011a, b; Kotov, Sinev, 2011]. The existence of a specific Far Eastern endemic complex of cladocerans was demonstrated in these papers, as well as the fact of penetration of some thermophylous species from southern regions to this basin.

One of the unexplored water bodies of the Far East, with only scarce data on planktonic crustaceans, is Lake Bolon. This lake is one of the largest water bod- ies of the Lower Amur River. It is located in Khabarovsk Territory of the Russian Federation on the edge of the Amur River lowland [Grigoriev, 1964]. The water-surface area of the lake is $338 \mathrm{~km}^{2}$ and the average depth is $4 \mathrm{~m}$. Its hydrological regime is regulated by the run-off to the Amur River, connected with the lake with two affluents [Nikonov, 1970]. The lake has a floodplain valley origin and represents a remainder of a huge lake-river basin, located here in the Lower Quaternary [Avarijaskin, 1970].

Until the last decade, data on the freshwater invertebrates of the lake were scarce [Mikulich, 1948; Khachina, 1948; Manuilova, 1964], although populations of several taxa were studied in detail in special taxonomic papers. Diaphanosoma dubium Manuilova, 1964 was described from Lake Bolon [Manuilova, 1964] and then redescribed in detail [Korovchinsky, 2000]. Later, the material from the lake and its basin was used for description of Leptodora richardi Korovchinsky, 2009 [Korovchinsky, 2009] and Diaphanosoma amurensis Korovchinsky et Sheveleva, 2009 [Korovchinsky, Sheveleva, 2009]. A complex description of the fauna of water invertebrates of the Bolonskiy State Nature Reserve, partly covering the aquatiria of the lake, has also been provided by Vshivkova \& Nikitina [2010]. Overall, to date only eight taxa of Cladocera have been identified in the lake and its vicinities: Daphnia sp., Bosmina sp., Chydorus sp. [Mikulich, 1948], Diaphanosoma dubium, D. amurensis, Leptodora richardi, Moina gouldeni Mirabdullaev, 1993 [Vshivkova, Nikitina, 2010], and Limnosida frontosa Sars, 1862 [Korovchinsky, 2014]. We do not find any identifications of the copepod species, except the subclass rank. Thus, fauna of the planktonic crustaceans of the Lake Bolon remains unknown despite its protected status and the commercial fishing importance.

The aim of the present study is to make an inventory of the Cladocera and Copepoda fauna of the Lake Bolon basin and evaluate the biogeographic status of the crustaceans found there.

\section{Material and methods}

Samples of zooplankton were collected in September 2007 in the vicinities of Djuen village, and in August 2016 in the Bolonskiy State Natural Reserve.

The Djuen village is located on the north-western shore of the Bolon Lake. Near it, a small river and numerous drainage channels are located. Zooplankton was collected from nine localities in Lake Bolon, its oxbows and temporary water bodies in its basin (Fig. 1, white squares).

Bolonskiy State Natural Reserve adjoins to Lake Bolon from the south-west (Fig. 1, gray squares), it occupies a territory between the Simmi and Harpi rivers and includes wetlands with an area more than 100 thousand hectares. The floodplains of rivers are a boggy plain covered with meadow vegetation or reed beds. In rivers and river spills, the macrophytes are widely 


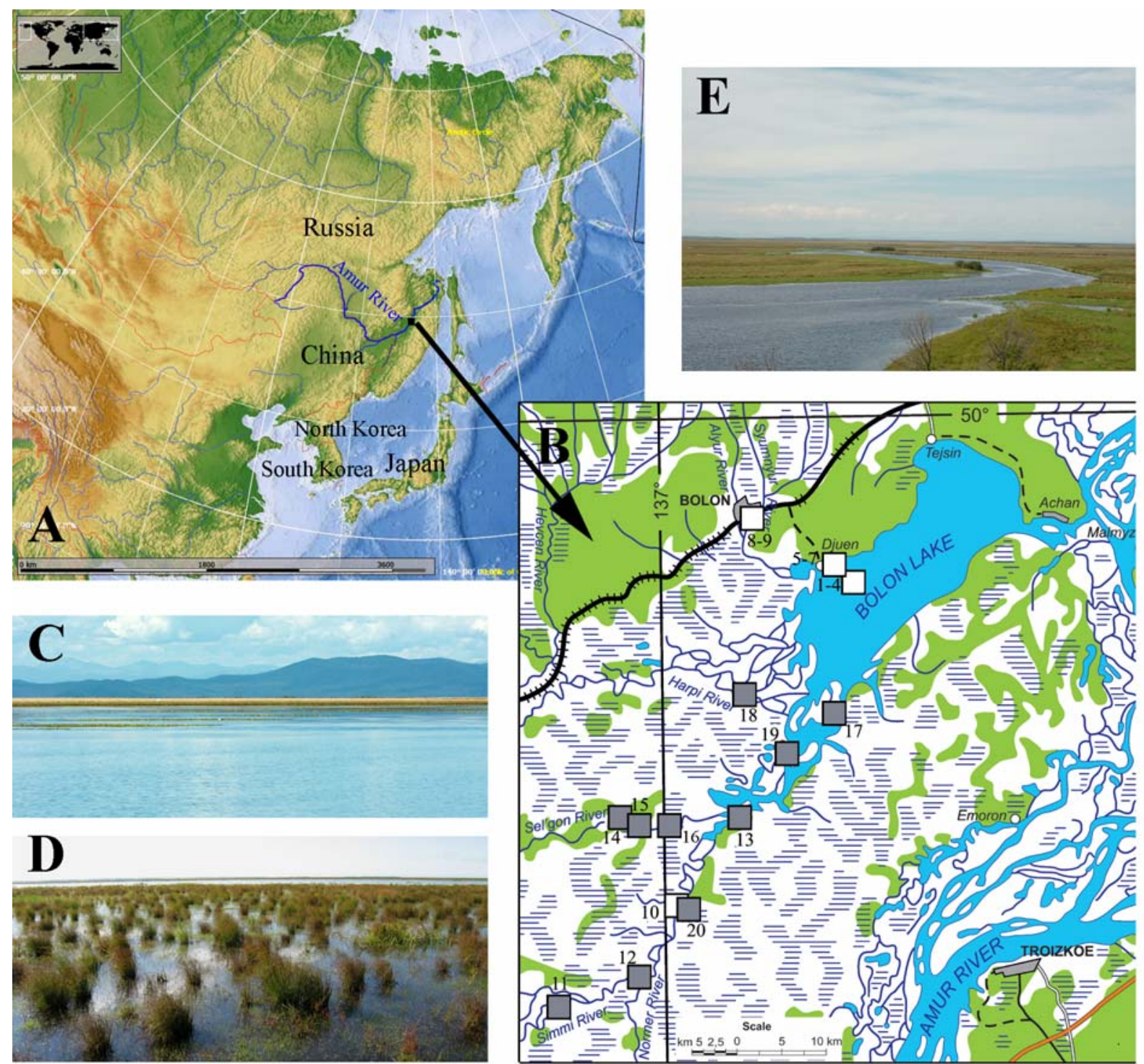

Fig. 1. Map of the region and photos of some localities. A - position of the region in Eastern Eurasia; B - map of region with sampling stations in September 2007 (white squares) and August 2016 (gray squares); C — pelagic zone of Lake Bolon (Locality 2); D its littoral zone (Locality 4); E - Kipru channel, near Kordon Kipru (Locality 10). The base map for A is the Marble Virtual Globe 1.5.1 "plain map" (i.e., no attributable data layers) available at https://marble.kde.org/. Photo D by A.A. Kotov, C and E - courtesy by M. Roshchin (published with his permission).

Рис. 1. Карта региона и фотографии некоторых водоемов. А - положение региона в Восточной Евразии; В - карта региона с отмеченными точками пробоотбора в сентябре 2007 г. (белые квадраты) и августе 2016 г. (серые квадраты); С - пелагиаль озера Болонь (точка 2); D - его литораль (местообитание 4); E - Канал Кипру около кордона Кипру (точка 10). Изначальная карта для фрагмента А взята с портала Marble Virtual Globe 1.5.1 “plain map" и доступна по адресу https://marble.kde.org/. Фото D сделано А.А. Котовым, С и Е - М. Рощиным (публикуется с его разрешения).

represented; thickets sometimes occupy more than half the area of the waterway. The most numerous macrophytes are the water nut (Trapa natans L.), the floating heart (Nymphoides peltata (S.G. Gmel.) Kuntze), the spatterdock (Nuphar sp.) and the pondgrass (Potamogeton natans L.). Zooplankton in this area was collected at 11 stations in the Simmi, Sel'gon, Harpi and Kirpu rivers, and also in the Albite Lake. At each station three replicate samples were collected by hauling a plankton net (diameter $0.1 \mathrm{~m}, 50 \mu \mathrm{m}$ mesh) vertically through the water column, engaging the upper layer of the bottom with the detached sediment filtered through the net up to the surface. Sampling was performed both from the shore and from the boat that enabled reaching the pelagic zone of the water bodies. The location of sampling stations is shown on Figure 1 and in Table 1.

All samples were preserved with $96 \%$ ethanol. All samples were provisionally investigated under stereoscopic and compound microscopes using standard techniques [Kotov, 2013]. General morphology of all found individuals was studied in toto under an Olympus BX41 
Table 1. Sampling localities in the Bolon Lake basin in 2007 and 2013. Таблица 1. Список местообитаний в бассейне Озера Болонь, откуда были взяты пробы в 2007 и 2013 годах.

\begin{tabular}{llll}
\hline No. & Water body & N, & $\mathbf{E}^{\circ}$ \\
\hline 1. & Littoral of Lake Bolon near Dzhuen & 49.85061 & 136.2652 \\
2. & Lake Bolon' about 300 m from the shore (pelagic and vegetation) & 49.8442 & 136.2761 \\
3. & A small puddle near Lake Bolon & 49.85353 & 136.2678 \\
4. & Littoral of Lake Bolon with numerous hillocks & 49.85242 & 136.2674 \\
5. & An affluent of River Sjumnjur (right bank), near railway station Bolon & 49.89845 & 136.1425 \\
6. & A puddle, right bank of River Sjumnjur, near railway station Bolon & 49.89836 & 136.1427 \\
7. & A puddle, leaf bank of River Sjumnjur, near railway station Bolon & 49.8968 & 136.1452 \\
8. & A puddle near a stream, railway station Bolon & 49.89786 & 136.1351 \\
9. & A ditch with vegetation, railway station Bolon & 49.8981 & 136.1381 \\
10. & Kipru channel, near Kordon Kipru & 49.50653 & 136.0273 \\
11. & River Simmy near Kordon Vakhtar & 49.41304 & 135.8447 \\
12. & River Simmy near mouth of Normen River & 49.43823 & 135.9643 \\
13. & River Simmy at Cheremshiniy Kordon & 49.59206 & 136.1261 \\
14. & River Selgon near Kordon Shelkovoy Griady & 49.59386 & 135.9275 \\
15. & River Selgon, Nymphaea patches & 49.58988 & 135.9659 \\
16. & River Se'lgon, a backward & 49.58374 & 136.0273 \\
17. & Ersun channel near Kordon Kiltasin & 49.70731 & 136.283 \\
18. & River Kharpy, 15 km from its mouth & 49.72874 & 136.1149 \\
19. & Lake Albite & 49.67973 & 136.1936 \\
20. & River Kipru, 4 km from Kordon Kipru & 49.50686 & 136.0455 \\
\hline
\end{tabular}

compound microscope. Then some individuals were dissected using tungsten needles electrolytically sharpened in $10 \% \mathrm{NaOH}$ [Frey, 1986]. Each dissected body part was transferred individually by aforementioned needles to a new drop of glycerol on a separate slide, covered by a cover slip and investigated in detail under an immersion lens at magnification $x$ 100. Drawings were prepared with a drawing tube attached to the light microscope Olympus BX 41 or Olympus CX 41. Morphological terminology is applied to Cladocera according to Kotov [2013].

We used the computer package EstimateS [Colwell, 2013] to estimate species richness of the Cladocerans in the region. Also a basic graph was made with the portion of water bodies where each taxon is recorded.

\section{Results}

\section{A. General}

Totally, 45 taxa of Cladocera are recorded, but four taxa were identified only to the genus level. Exact identification was not possible when the samples contained juvenile specimens only. In the case of Diaphanosoma sp., few samples contained juvenile D. brachiurum-like females which, most probably, belong to $D$. amurensis. These two taxa could not be discriminated based on female morphology [Korovchinsky, 2018], and we prefer to avoid exact species identification. Thirteen taxa of Copepoda are identified, many samples contained only copepodites, the species identification of which was impossible. Some remarkable taxa are discussed below.

\section{B. Taxonomic account on selected species}

Superorder Cladocera Latreille, 1829

Order Ctenopoda Sars, 1865

Family Sididae Baird, 1850

Sida crystallina (O.F. Müller, 1776)

Fig. 2A-E.

Parthenogenetic female. Body ovoid, head small with a large anterior and a pair of smaller anchoring organs (Fig. 2A, B) dorsally, dorsal margin convex, its postero-dorsal angle expressed, posterion margin straight, postero-ventral margin expressed, bearing a spine. Rostrum relatively long and either straight or slightly curved, directed ventrally, compound eye large, situated near ventral head margin, ocellus very small (Fig. 2B, C). Postabdomen trapezium-shaped, its ventral margin straight, proximal portion of dorsal side of postabdomen weakly prominent (Fig. 2E). Row of 1416 anal teeth along each lateral side noticeably curved, rows of minute spinules near these teeth. Postabdomi- 


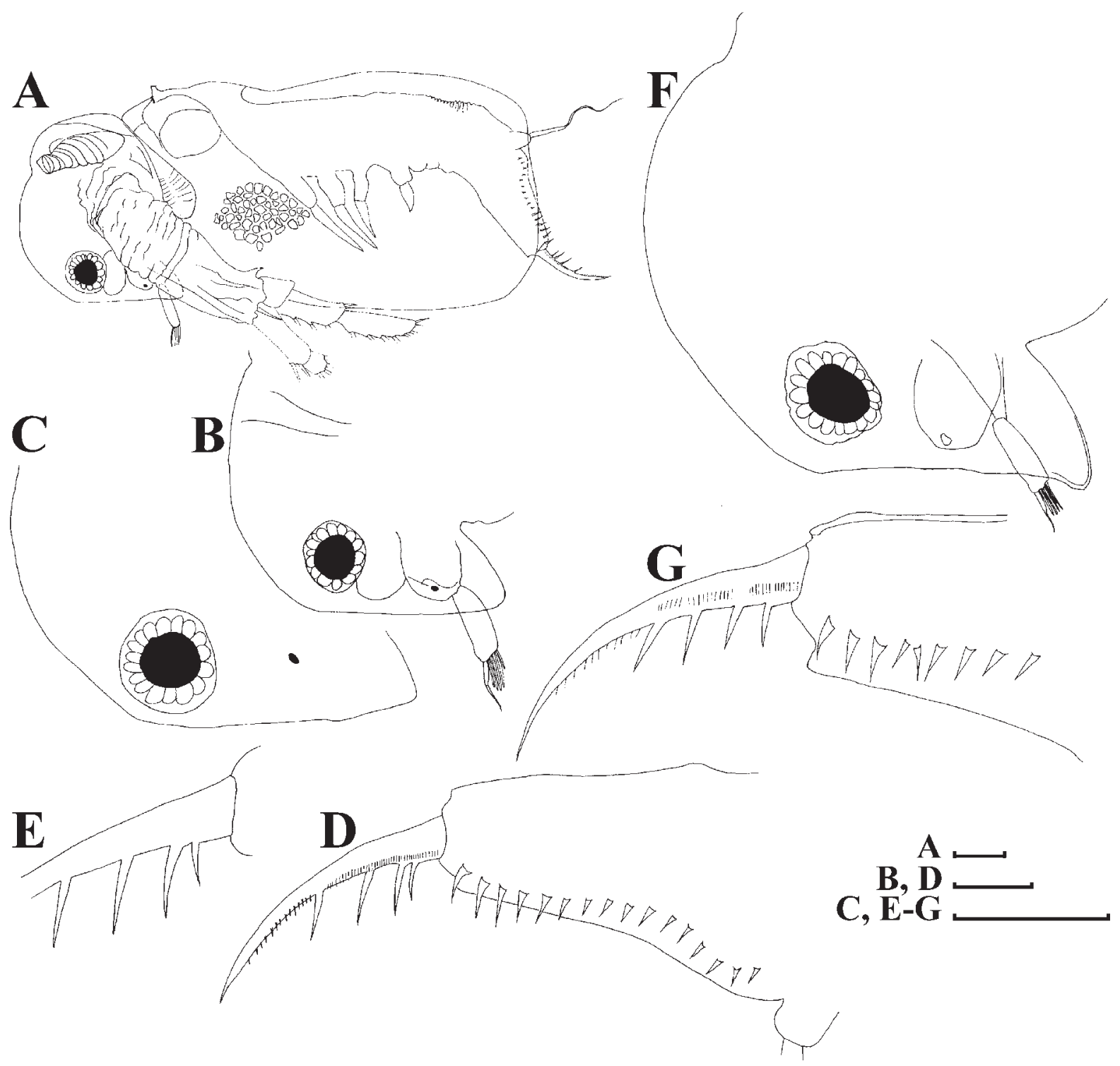

Fig. 2. Parthenogenetic females of Sida crystallina from Kipru channel, near Kordon Kipru, locality 10 (A-E) and S. ortiva from River Simmy at Cheremshiniy Kordon, locality 13 (F-G). A - lateral view; B-C - head; D-E - postabdomen and postabdominal claw; F head; $\mathrm{G}$ - distal portion of postabdomen. Scale bars: $0.1 \mathrm{~mm}$.

Рис. 2. Партеногенетическая самка Sida crystallina из протоки Кипру около кордона Кипру, точки 10 (А-Е) и S. ortiva из Реки Симми около Черемшиного кордона, точки $13(\mathrm{~F}-\mathrm{G})$. А — вид сбоку; B-C — голова; D-E - постабдомен и постабдоминальный коготок; F — голова; G — дистальная часть постабдомена. Масштабная линейка: 0,1 мм.

nal claw regularly bent, with four basal spines, proximalmost spine small and situated closely to the neighboring one (Fig. 2E). Postabdominal setae long, about 0.4 of body length, located on a strong projection. Antenna I long, with distal aesthetascs and distal sensory seta longer than the former (Fig. 2B). Antenna II long, its basal segment long, with some spines distally (Fig. 2A). Formula of antennal setae: $0-4-7 / 0-1-4$. Six pairs of thoracic limbs of typical structure for $S$. crystallina (see Korovchinsky [2004]. Body size range 1.7-4.0 mm.

Comments. See comments on the following species.
Sida ortiva Korovchinsky, 1979

Fig. 2F-G.

Parthenogenetic female. Body structure similar to that of S. crystallina. Rostrum relatively short, directed ventrally and curved, compound eye large, situated near ventral head margin, ocellus very small (Fig. 2F). Postabdomen trapezium-shaped, dorsum of postabdomen with weakly prominent proximal part. Row of 12 14 anal teeth along each lateral side noticeably curved, rows of minute spinules near these teeth. Postabdominal claw regularly bent, with four basal spines, proxi- 
malmost spine is relatively large, almost of the same size as the neighboring one (Fig. 2G). Postabdominal setae long, about 0.4 of body length, located on a strong projection. Antenna I long, with distal aesthetascs and distal sensory seta longer than the former ones (Fig. 2F). Other structures as in previous species. Body size $1.5-3.0 \mathrm{~mm}$.

Comments. Korovchinsky [1979] suggested that two subspecies exist in northern Eurasia: S. cystallina crystallina (O.F. Müller, 1776) and S. crystallina ortiva Korovchinsky, 1979. Now they are regarded as separate species due to high genetic differences and wide range overlapping [Kotov et al., 2011a; Korovchinsky, 2018]. S. crystallina differs from $S$. ortiva in (1) longer rostrum projected posteriorly and (2) conspicuously smaller proximalmost basal spine on postabdominal claws located closely to the neighboring one. In the Amur River basin both taxa are present [Kotov et al., 2011a]. In few localities in Lake Bolon basin, both species are found to co-occur.

Order Anomopoda Sars, 1865

Family Chydoridae Dybowski et Grochowski, 1894 emend. Frey 1967

Subfamily Aloninae Dybowski et Grochowski, 1894 emend. Frey, 1967

Acroperus harpae Baird, 1834

Fig. 3.

Parthenogenetic female. Body low oval, elongated in lateral view (Fig. 3A). Having a well-expressed dorsal keel with variable shape with out separation on carapace and head. Dorsal margin which moderately convex, evenly arched from the tip of rostrum to the postero-dorsal angle that rounded, posterior margin weakly to moderately concave, postero-ventral angles broadly rounded. Ventral margin relatively convex and armed with 39 setae (Fig. 3C). Rostrum truncated, pointed downward and oval (Fig. 3A, B). Head pores as for Chydoridae, three connected head pores and two minute lateral pores. Labrum relativity small, with subtriangular keel, without setules on apex (Fig. 3B). The row of setae covers all margin, they are different size in certain sections (Fig. 3A, C). Postabdomen long and narrowing, with parallel margin or slightly narrowing distally, its length about $4 \mathrm{X}$ height (Fig. 3H). Preanal portion convex, preanal angle faintly defined, anal margin almost straight, postanal angle not defined, postanal margin almost straight; postanal portion not much longer than anal one. Postanal and anal margin with groups of minute denticles (Fig. 3H, I). Laterally 13 series of fascicles of long setules. The base of postabdominal claw carries a cluster of long setules. Postabdominal claw long, straight, with slightly curved tip. Basal spine long, straight and thin, about 0.18 length of claw, bearing 5 setules. At the middle of the claw is a prominent spine. (Fig. 3I).

Antenna I long and narrow (its length about $4 \mathrm{X}$ width), with three groups of fine setules at anterior face; among nine aesthetascs two longer than the rest, longest aesthetascs longer than antenna I; antennular seta thin and long, about 1/2 length of antenna I, protruding somewhat $1 / 3$ to distal (Fig. 3F). Antenna II relativity long, antennal formula: setae $0-0-3 / 0-1-3$, spines 1-0-1/0-0-1. Apical setae differentiated in size, apical spines about $1 / 3$ length of apical segments, spine on proximal exopod segment about $1 / 2$ of length itself (Fig. 3G). Limb I with ODL bearing a long seta, armed with short setules distally; IDL with three setae, seta 2 and 3 large, 2-segmented, a little shorter than ODL seta; (Fig. 3J). Size in our material $0.72 \mathrm{~mm}$.

Comments. See comments on the following taxon.

\section{Acroperus angustatus Sars, 1863}

Fig. 4.

Parthenogenetic female. Body shape variable, mostly suboval and elongated in lateral view (Fig. 4A). Having a well-expressed dorsal keel as in previous species with variable shape. Dorsal margin weakly convex, in some specimens with discernible separation. Postero-dorsal angle weakly identified, posterior margin relatively concave, postero-ventral angles broadly rounded with 1-3 saw-like denticles Fig. 4D). Ventral margin convex and armed with 44 different size setae (Fig. 4C). Rostrum truncated, pointed downward and oval (Fig. 4A, B). Head pores and labrum as in previous species (Fig. 4B). Postabdomen same as for previous species. Antenna I most as for previous species except longest terminal aesthetasc which is relatively longer (Fig. 4F). Antenna II shorter than previous, antennal formula: setae $0-0-3 / 0-1-3$, spines $1-0-1 / 0-0-$ 1. All apical setae relatively similar in size, apical spines same as for previous (Fig. 4G). Limb I with ODL bearing a long seta, armed with short setules distally; IDL with three setae, seta 3 long as ODL and 2 shorter than 3; (Fig. 4J). Size in our material $0.65 \mathrm{~mm}$.

Comments. Sinev [2009] demonstrated that two aforementioned taxa are morphologically close, and both are widely distributed in Northern Eurasia from Europe to Far East. We confirm that both taxa are common in the Lake Bolon basin.

\section{Camptocercus uncinatus Smirnov, 1971} Fig. 5.

Parthenogenetic female. Body ovoid, elongated in lateral view (Fig. 5A); strongly compressed laterally and having a well-expressed dorsal keel both on carapace and head. Dorsal margin without depression between valves and head shield, postero-dorsal angle broadly rounded, posterior margin convex, posteroventral angles broadly rounded. Ventral margin slightly undulated. Rostrum acute, pointed downward (Fig. 5A, B). Three connected main head pores, lateral pores minute. Labrum with a sub-triangular keel; its posterior margin without a denticle, with two groups of fine setules (Fig. 5B). Row of ventral setae followed by a row of fine setules, in dorsal portion of posterior mar- 


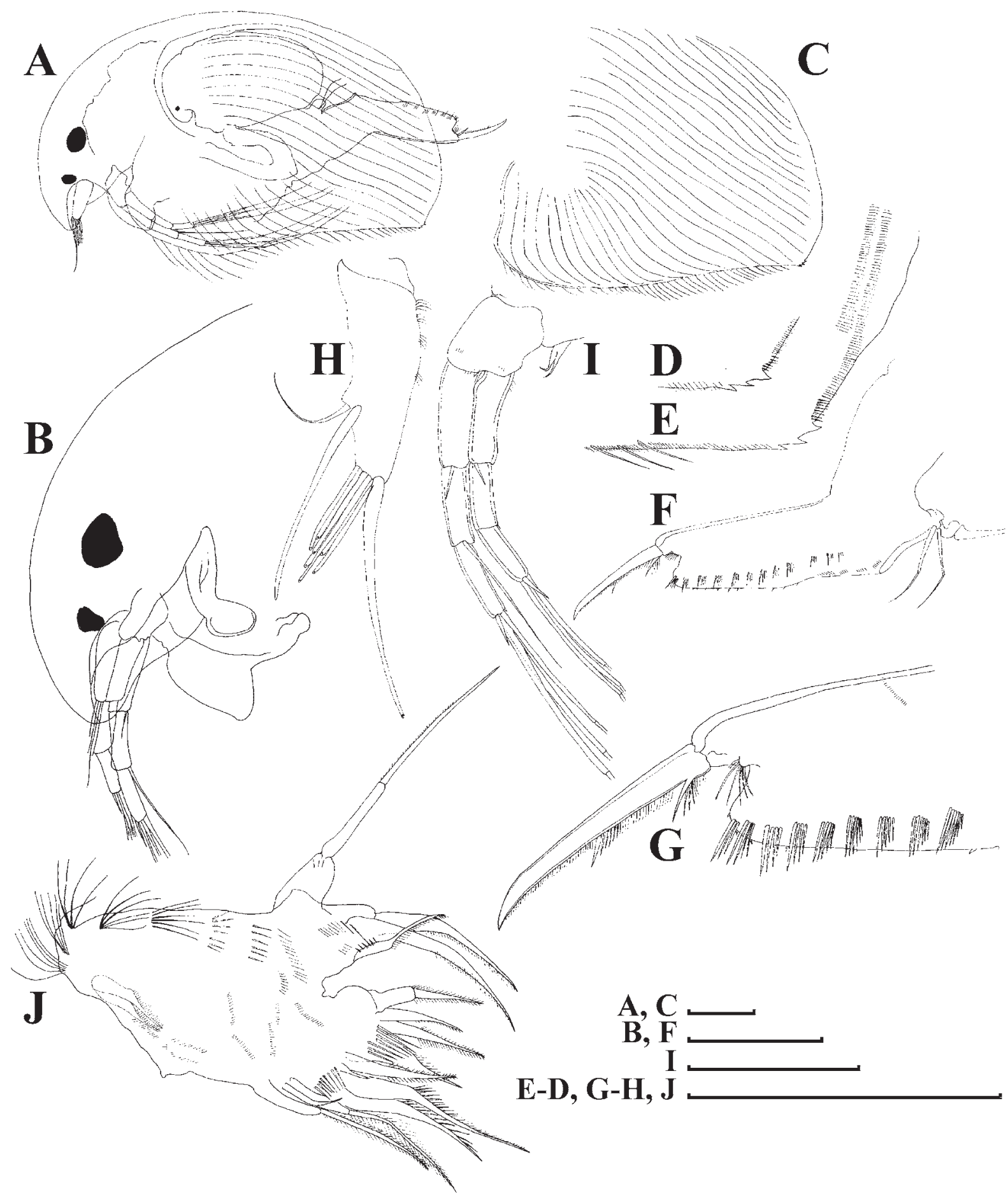

Fig. 3. Parthenogenetic female of Acroperus harpae from an affluent of River Sjumnjur (right bank), near railway station of Bolon, locality 5. A - general view; B - head; C - valve; D-E - armature of postero-ventral angle; F — postabdomen; $\mathrm{G}$ - its distal portion; $\mathrm{H}$ - antenna I; I — antenna II; J — limb I. Scale bars: $0.1 \mathrm{~mm}$.

Рис. 3. Партеногенетическая самка Acroperus harpae из заводи на правом берегу речки Сюмнюр у станции Болонь, точки 5. А общий вид; В - голова; C - створка; D-E — вооружение заднебрюшной части створки; F — постабдомен; G - его дистальная часть; H - антенна I; I — антенна II; J — торакопод I. Масштабная линейка: 0,1 мм.

gin they are strong, denticle-like (Fig. 5C-D). Postabdomen very long, narrowing distally, length about 5$6 \mathrm{X}$ height (Fig. 5H). Preanal portion almost straight, preanal angle well-developed, anal margin almost straight, postanal angle not expressed, postanal margin straight to slightly concave; postanal portion 3-4 times longer than anal one. Postanal margin with about 19 clustered postanal denticles with fused bases (Fig. $5 \mathrm{H}$ ). 


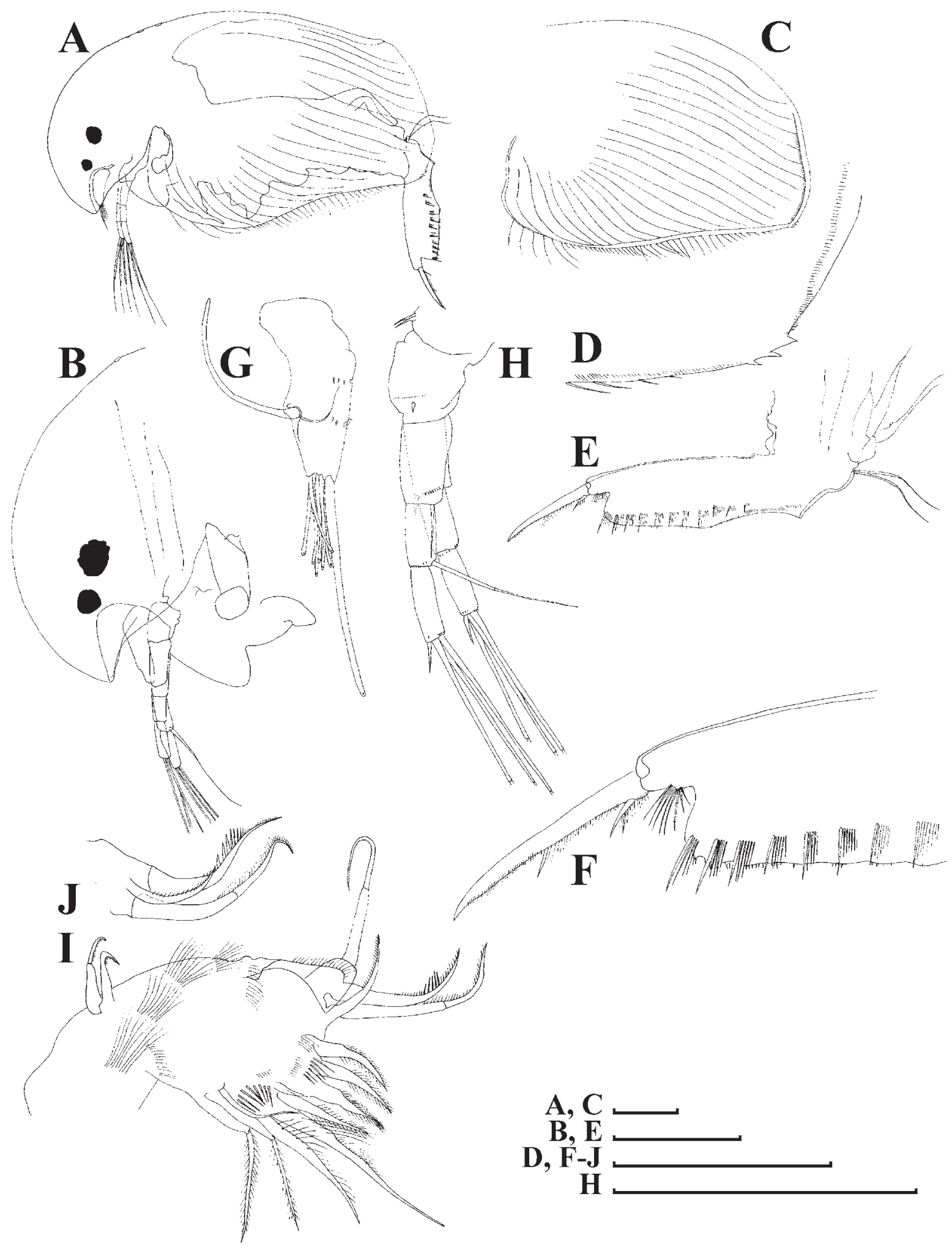

Fig. 4. Parthenogenetic female of Acroperus angustatus from River Simmy near mouth of Normen River, locality 12. A - general view; B — head; C — valve; D — armature of postero-ventral angle; E — postabdomen; F — its distal portion; G — antenna I; H antenna II; I — limb I; J — its inner-distal lobe. Scale bars: $0.1 \mathrm{~mm}$.

Рис. 4. Партеногенетическая самка Acroperus angustatus из Реки Симми около устья реки Нормен, точки 12. А - общий вид; В — голова; С - створка; D - вооружение заднебрюшного края створки; Е — постабдомен; F — его дистальная часть; $\mathrm{G}$ антенна I; H - антенна II; I — торакопод I; J — его внутренняя дистальная доля. Масштабная линейка: 0,1 мм. 


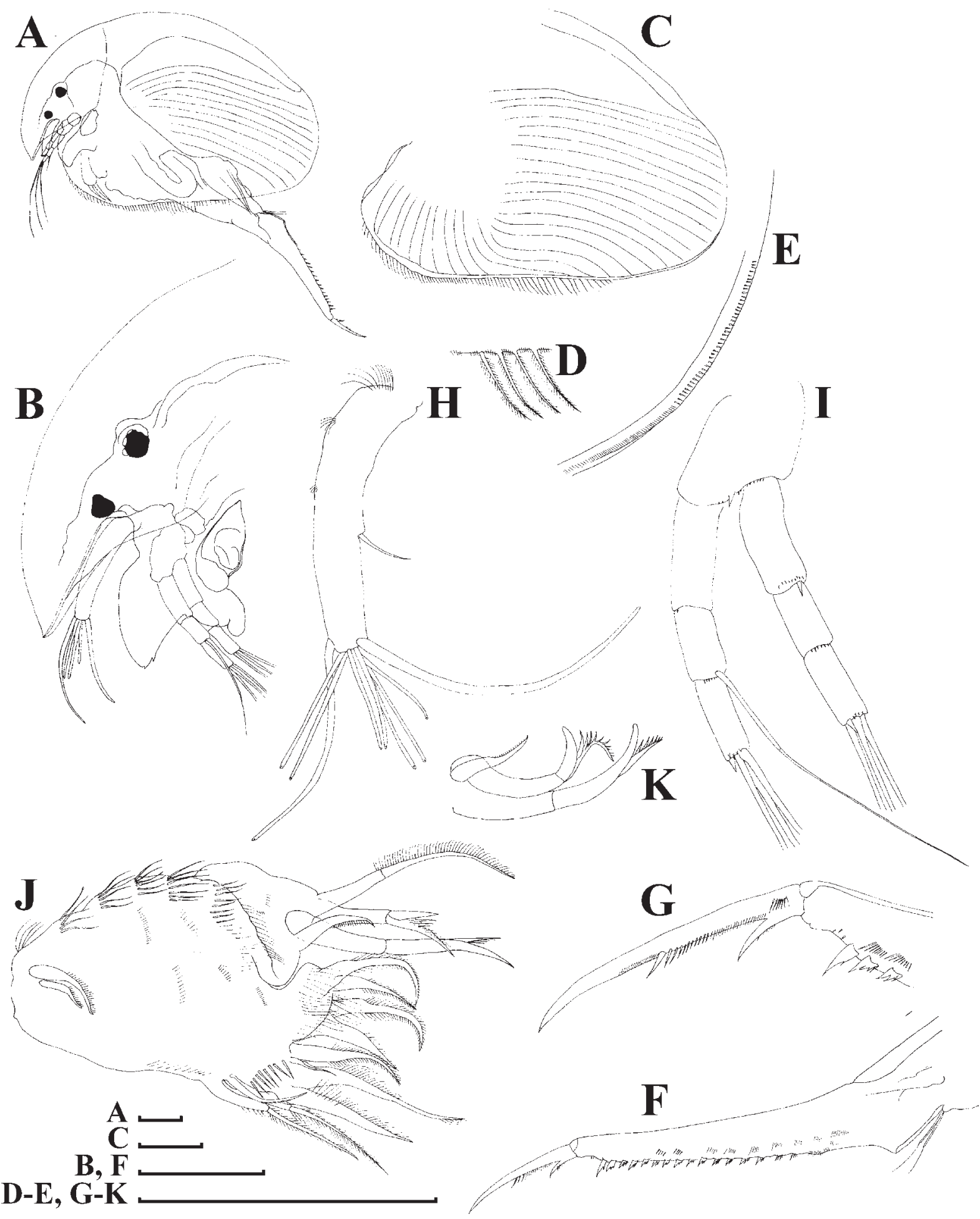

Fig. 5. Parthenogenetic female of Camptocercus uncinatus from Lake Albite, locality 19. A — general view; B — head; C — valve; D armature of ventral margin; $\mathrm{E}$ - armature of postero-ventral valve portion; $\mathrm{F}$ - postabdomen; $\mathrm{G}$ — its distal portion; $\mathrm{H}$ - antenna I; I antenna II; J — limb I; K — inner-distal lobe. Scale bars: $0.1 \mathrm{~mm}$.

Рис. 5. Партеногенетическая самка Camptocercus uncinatus из Озера Альбите, точки 19. А - общий вид; В — голова; С створка; D — вооружение брюшного края; Е — вооружение заднебрюшного края; F — постабдомен; G — его дистальная часть; H антенна I; I — антенна II; J - торакопод I; K — его внутренняя дистальная доля. Масштабная линейка: 0,1 мм. 
Laterally series of fine setules. Postabdominal claw long, straight, with slightly curved tip; basal spine short, slightly bent, about 0.16 length of claw; few setules at the end of proximal pecten as strong spines (Fig. $5 \mathrm{H}$, I). Antenna I with length about 3-4 width, with three groups of fine setules at anterior face; among nine aesthetascs two longer than the rest, longest aesthetascs as long as antenna I; antennular seta thin, about $1 / 5$ length of antenna I, protruding somewhat distally to middle (Fig. 5F). Antenna II short, antennal formula: setae 0-0-3/0-1-3, spines 1-0-1/0-0-1. Apical setae subequal in size, apical spines very short, spine on proximal exopod segment also very short (Fig. 5G). Limb I with ODL bearing a long seta, armed with long setules; IDL with three setae, seta 1 large, well developed, about 1/3 length of ODL seta; setae 2 and 3 thick, curved, hook-like, with a short, setulated distal portion (Fig. 5J-K). Size in our material $0.73-0.75 \mathrm{~mm}$.

Comments. Earlier Kotov et al. [2012] concluded that there are two close species in Korea: $C$. uncinatus Smirnov, 1971 (widely distributed in East Asia) and $C$. vietnamensis Than, 1980 (thermophylous taxon with a predominantly tropical-subtropical distribution, penetrating North up to Korean Peninsula). We did not fond the latter in the Bolon region, while $C$. uncinatus is a usual taxon there, while the northernmost limit of $C$. vietnamensis distribution is located in the Korean Peninsula.

\section{Camptocercus lilljeborgi Smirnov, 1971} Fig. 6.

Parthenogenetic female. Body low oval, elongated in lateral view (Fig. 6A); strongly compressed laterally and having a well-expressed dorsal keel both on carapace and head. Dorsal margin evenly arched from the tip of rostrum to the postero-dorsal angle, which is broadly rounded, posterior margin convex, posteroventral angles very broadly rounded. Ventral margin slightly undulate and armed with 61 setae. Rostrum truncated, pointed downward (Fig. 6A, B). Head pores as for genus. Labrum relativity wide, with two or four groups of fine setules (Fig. 6B). The row of setae reach $2 / 3$ length of margin, in that portion of posterior margin they are strong, denticle-like (Fig. 6C-D). Postabdomen very long, narrowing distally, length about $7 \mathrm{X}$ height (Fig. 6H). Preanal portion almost straight, preanal angle well-developed, anal margin almost straight, postanal angle not expressed, postanal margin almost straight; postanal portion 4 times longer than anal one. Postanal margin with about 20 clustered postanal denticles with fused bases (Fig. 6H). Laterally a series of fine setules. Postabdominal claw long, straight, with slightly curved tip; basal spine short, slightly bent, about $0.17 \mathrm{X}$ length of claw; few setules at the end of proximal pecten as strong spines (Fig. 6I). Antenna I with length about 3-4X width, with three groups of fine setules at anterior face; among nine aesthetascs two longer than the rest, longest aesthetascs as long as antenna I; antennular seta thin, about $1 / 5$ length of antenna I, protruding somewhat distally to middle (Fig. $6 \mathrm{~F})$. Antenna II short, antennal formula: setae 0-0-3/01-3, spines 1-0-1/0-0-1. Apical setae subequal in size, apical spines very short, spine on proximal exopod segment also very short (Fig. 6G). Limb I with ODL bearing a long seta, armed with long setules; IDL with three setae, seta 1 large, well developed, about $1 / 3$ length of ODL seta; setae 2 and 3 thick, curved, hooklike, with a short, setulated distal portion (Fig. 6J-K). Size in our material $0.73-0.75 \mathrm{~mm}$.

Comments. C. lilljeborgi is regarded to be a rare Palearctic species [Smirnov, 1971]. To date it was recorded from North and Central Europe (Germany, Romania, Slovenia, Sweden and Northern part of European Russia [Smirnov, 1998; Hudec, 2010]) and North-East Asia (several localities in Yakutia and Chukotka Peninsula [Streletskaya, 2010; Sinev, 2014; Kotov, 2016]. In this paper, this taxon is reported from the Amur basin for the first time. Our population is the southernmost Asian one to date, separated by about $1000 \mathrm{~km}$ from the closest known Asian population (Central Yakutia). Sinev [2014] suggested that although this species is widely distributed throughout Northern Eurasia it was overlooked by researchers due to its rarity.

\section{Kurzia latissima Kurz, 1875 Fig. 7.}

Parthenogenetic female. Body ovoid, high in lateral view, dorsal margin regularly curved from tip of rostrum to slightly expressed postero-dorsal angle, posterior margin convex, postero-ventral angle rounded, ventral margin with a prominence anteriorly to middle (Fig. 7A). Body compressed laterally, with a medial keel on carapace, but not on head. Rostrum relatively short, ocellus about half size of compound eye (Fig. 7B). Three major head pores connected, posterior pore transversely elongated, lateral pores minute. Labrum with large, triangular labral keel, anterior margin, its apex with round tip (Fig. 7B). Setules on posterior margin different in size (Fig. 7C-D). Postabdomen distally elongated, with concave postanal margin; dorso-distal angle of postabdomen recognized; postanal teeth about 11 (Fig. 7C). Postabdominal claw long, slightly curved, with a single long basal spine (as long as two claw widths), bearing a series of 5-6 thin spinules (Fig. 7G-H). Antenna I elongated, sensory seta in proximal part, nine aesthetascs of unequal size, three longest ones almost reach tip of rostrum (Fig. 7E). Antenna II short, antennal formula: setae $0-0-3 / 1-1-3$, spines 10-1/0-0-1(Fig. 7F). Limb I with ODL bearing a single bisegmented seta, setulated distally (Fig. 7I), IDL with three setae, distal portion with a row of setules decreasing to tip (Fig. 7D-E). Size in our material $0.57 \mathrm{~mm}$.

Comments. $K$. latissima is described from the Lake Bolon area for the first time. This taxon is common in the Lake Khanka area (Kotov, unpublished) as well as from China [Chiang, Du, 1979]. 


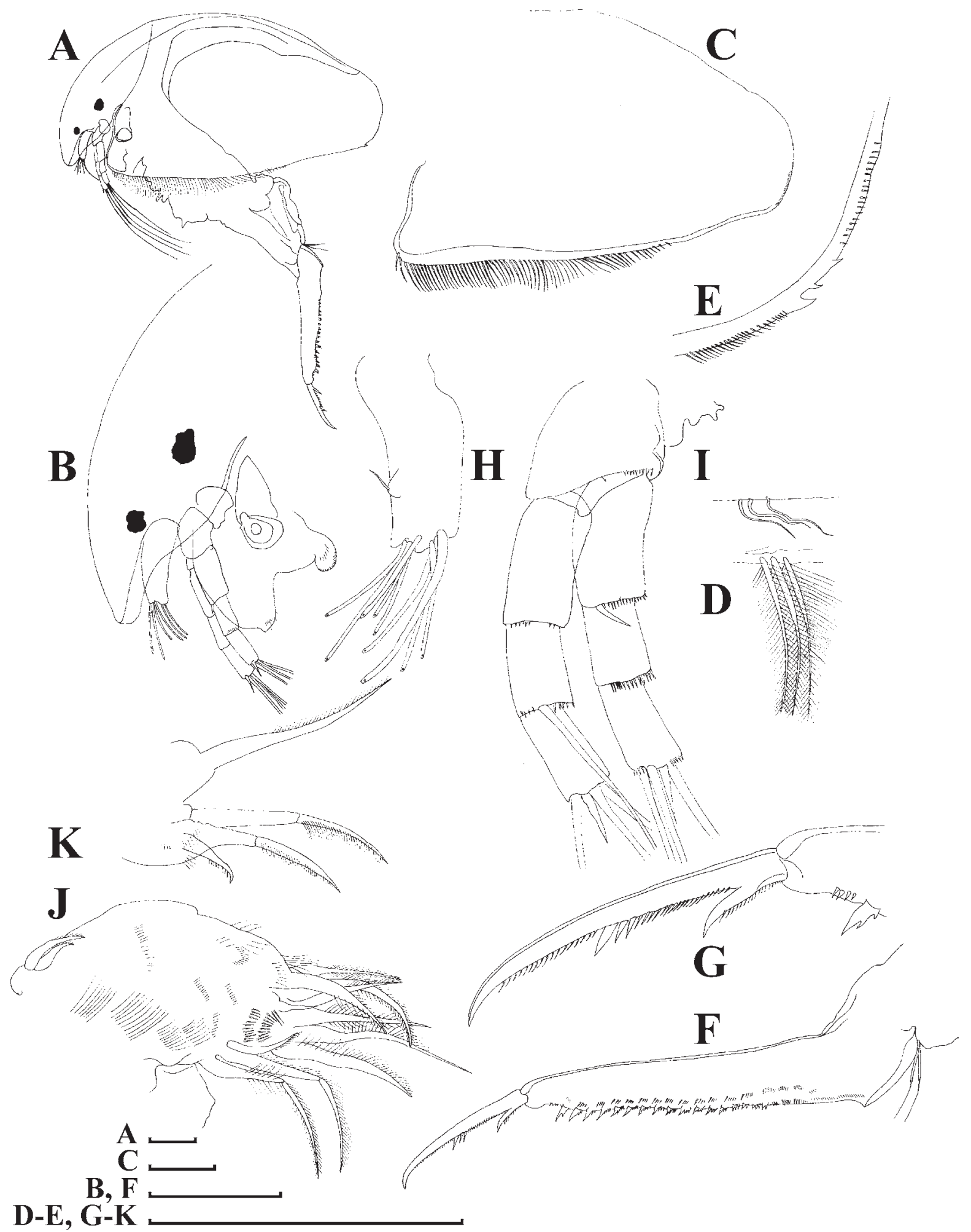

Fig. 6. Parthenogenetic female of Camptocercus lilljeborgi from Lake Albite, locality 13. A - general view; B — head; C — valve; D armature of ventral margin; $\mathrm{E}$ - armature of postero-ventral valve portion; $\mathrm{F}$ - postabdomen; $\mathrm{G}$ — its distal portion; $\mathrm{H}$ - antenna I; I antenna II; J - limb I; K - its distal portion. Scale bars: $0.1 \mathrm{~mm}$.

Рис. 6. Партеногенетическая самка Camptocercus lilljeborgi из озера Альбите, точки 19. А — общий вид; В — голова; С створка; D — вооружение брюшного края; Е — вооружение заднебрюшной части створки; F — постабдомен; $\mathrm{G}$ - его дистальная часть; Н - антенна I; I - антенна II; J — торакопод I; K - его дистальная часть. Масштабная линейка: 0,1 мм. 


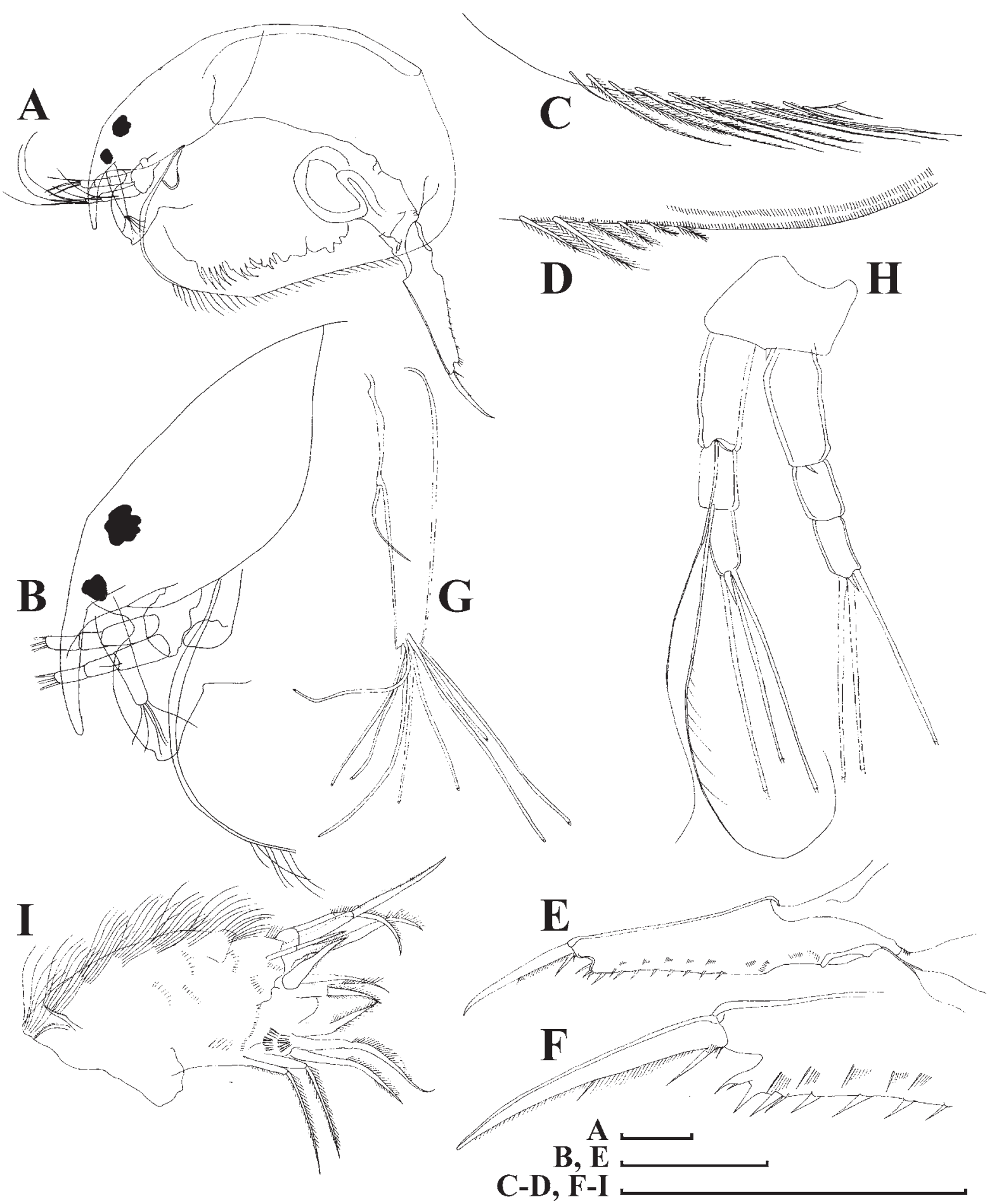

Fig. 7. Parthenogenetic female of Kurzia latissima from River Simmy near Kordon Vakhtar, locality 11. A — general view; B — head; C-D - armature of postero-ventral valve portion; E - postabdomen; F — its distal portion; G — antenna I; H - antenna II; I - limb I. Scale bars: $0.1 \mathrm{~mm}$.

Рис. 7. Партеногенетическая самка Kurzia latissima из реки Симми рядом с кордоном Вахтар, точки 11. А - общий вид; В голова; C-D - вооружение заднебрюшной части створки; Е — постабдомен; F — его дистальная часть; G — антенна I; H антенна II; I - торакопод I. Масштабная линейка: 0,1 мм. 


\section{Alona cf. affinis (Leydig, 1860)}

Figs. 8-9.

Parthenogenetic female. In lateral view, body oval (Fig. 8A), of moderate height, moderately compressed laterally. Maximum height at the middle of the body. In adults height/length ratio about 0.6. Dorsal margin of valves convex; postero-dorsal and postero-ventral angles broadly rounded. Posterior margin convex. Antero-ventral angle rounded. Ventral margin (Fig. 8B) weakly convex to straight, with $70-85$ setae. About 25 anteriormost setae very long, next 10 seta short, posterior 40 setae of moderate length, decreasing in length posteriorly. Postero-dorsal angle (Fig. 8C-E) with 1-4 denticles closely spaced denticles of variable shape, at least one - with broad base, and one-two group of short setules of similar length and thickness, with 3-5 setules in each. A row of about 100 setules of variable length along posterior margin on inner side of carapace, these setules not organized into groups. Carapace ornamentation as weakly developed longitudinal lines and dense longitudinal striae between them. Head relatively small, low triangle-rounded in lateral view. In lateral view rostrum relatively narrow, protruding downwards. Ocellus of moderate size, eye larger than ocellus. Distance from tip of rostrum to ocellus 1.5-2 times greater than that between ocellus and eye. Head shield (Fig. 8F) with maximum width behind mandibular articulation, covered by fine striae as on the valves. Rostrum short and rounded. Posterior margin as prominent, acute distal angle. Two major head pores (Fig. 8G) of same size, with a narrow connection between them. PP slightly less than 2 IP in adults. Lateral head pores located in small depressions more than 1 IP distance from midline, at level before anterior major head pore. Striae absent around head pores. A small pore like thickening is located behind the posterior angle of head shield. Labrum of moderate size. Labral keel moderately wide, with a blunt apex. Anterior margin of keel in studied specimens polygonal, posterior margin weakly convex to straight, with two clusters of short setules. Thorax two times longer than abdomen. Dorsal surface of abdominal segments not saddle-shaped. Abdominal joint not developed. Postabdomen (Fig. 8H) large, subrectangular, moderately high, with parallel margins, weakly narrowing at the end. Length about 2.5 height. Ventral margin straight. Basis of claws bordered from distal margin by clear incision. Distal margin almost straight; distal angle rounded, sometimes weakly protruding. Dorsal margin weakly convex to straight in postanal portion and weakly concave in anal one, with distal part about 2.5 times longer than preanal one, with postanal portion 2.5-2.8 times longer than anal one. Preanal angle well expressed, postanal angle not defined. Preanal margin almost straight (Fig. 8I), with 11-13 well-developed, sharp composite denticles, each with 2-4, rarely 5, spinules along anterior margin; size of denticles increasing distally. Length of longest denticles about $1.5 \mathrm{X}$ the width of base of postabdominal claw, more than 3 times exceeding the width of the denticle base. Postanal portion with 10-12 broad lateral fascicles, posteriormost setule of each fascicle longest, thicker than others, 1.5 times shorter than neighboring marginal denticles. Anal portion with several smaller fascicles, spaced irregularly. Postabdominal claw (Fig. 1J) of moderate length, slightly longer than preanal portion of postabdomen. Basal spine long and slender, about 0.35 length of the claw. A row of 7-10 long setules between basal spine and the base of postabdomen. Antenna I (Fig. 8K) of moderate size, length about 3 widths, with a cluster of 3-4 long setules about one third the length of antennule at anterior face. Antennular seta thin, more than $1 / 2$ length of antennule, arising terminally. Nine terminal aesthetascs, two of them long and thick, longer than antenna I itself, all others much shorter, about $1 / 2-1 / 3$ the length of antenna I. Antenna II relatively short (Fig. 8L). Antennal formula, setae $0-0-3 / 1-1-3$, spines $1-0-1 / 0-0-1$. Basal segment robust, with very short seta between branches, branches relatively short, all segments cylindrical, slender. In each branch the basal segment is longest, middle segment slightly shorter than apical segment. Seta arising from basal segment of endopodite thin, reaching above the end of endopodite. Seta arising from middle segment of endopodite, of similar size to apical setae. Two shortest apical setae on exopodite and two on endopodite with a very long spinule at the point of articulation. Spine on basal segment of exopodite slightly longer than middle segment. Spines on apical segments much shorter than apical segments.

Limb I of moderate size (Fig. 9A-C), with ovoid epipodite. A long accessory seta only slightly shorter than ODL seta, with long setules in distal part. ODL with one seta. IDL with three setae and several clusters of hard setules. IDL seta 1 large and broad, claw-like, strongly curved, slightly longer than seta 2; IDL setae 2 and 3 with thin setules in distal part, seta 3 slightly shorter than ODL seta, seta 2 about $2 / 3$ the length of seta 3 . Endite 3 with four setae subequal in length. Endite 2 (Fig. 3C) with two long distally setulated setae (e-f), a shorter seta near their base (d) and a naked inner seta (2) and small sensillum on anterior face of limb; seta e long, two times longer than seta $\mathrm{f}$. Endite 1 with two 2 -segmented setae $(\mathrm{g}-\mathrm{h})$, both setulated in distal part, a flat plumose seta pointed the limb base (i), and a naked inner seta (3). Inner seta 31.5 times longer than inner seta 2 Seven-eight rows of thin long setules on ventral face of limb. Two ejector hooks, one slightly shorter than other. Maxillar process elongated, with a short setulated seta in distal part (not represented in Fig. 9A).

Limb II subtriangular (Fig. 9D-E). Exopodite (Fig. 9, E: ext) elongated, with a slender seta as long as exopodite body itself, and a cluster of very long setules distally. Eight scraping spines, increasing in length distally, scraper 4 being significantly shorter than scrapers 3 and 5. Size of denticles on basal part of spines decreasing from basal to distal spines. Distal armature 


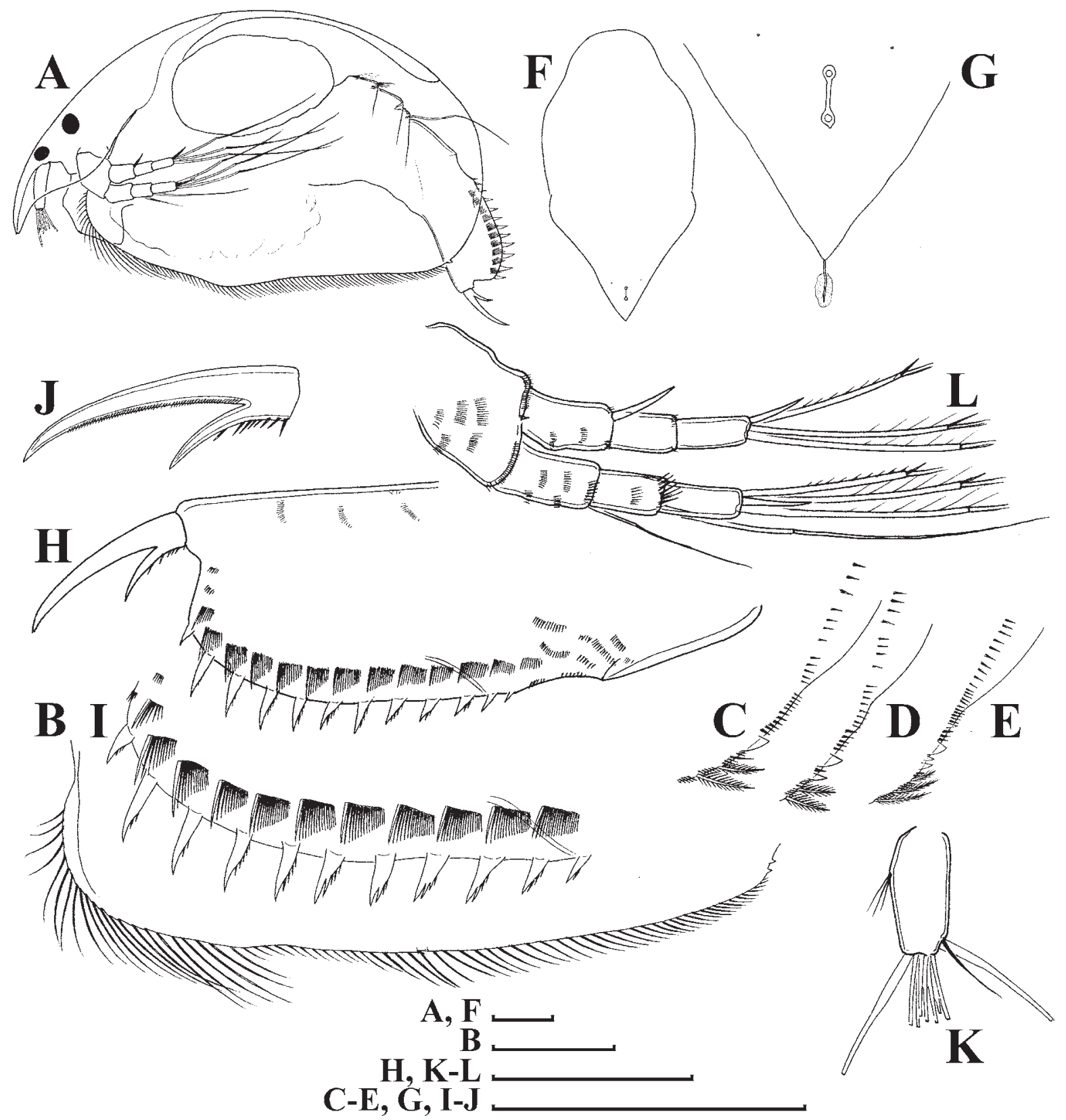

Fig. 8. Parthenogenetic female of Alona cf. affinis from River Kharpy, $15 \mathrm{~km}$ from its mouth, locality 19. A - general view; B valve; $\mathrm{C}-\mathrm{E}$ - armature of postero-ventral valve portion; $\mathrm{F}$ - head shield; $\mathrm{G}$ — dorsal head pores; $\mathrm{H}$ - postabdomen; I - its dorso-distal portion; J - postabdominal claw; K — antenna I; L — antenna II. Scale bars: $0.1 \mathrm{~mm}$.

Рис. 8. Партеногенетическая самка Alona cf. affinis из реки Харпи 15 км вверх от устья, точки 19. А - общий вид; В створка; C-E - вооружение заднебрюшной части створки; F - головной щит; G - спинные головные поры; Н - постабдомен; I - его дорсодистальная часть; J — постабдоминальный коготок; K — антенна I; L — антенна II. Масштабная линейка: 0,1 мм.

of gnathobase with four elements. Filter plate II with seven setae, the posteriormost member shorter than others.

Limb III (Fig. 9F-G) with ovoid epipodite lacking a projection. Exopodite of irregular shape, with seven setae. Seta 3 being longest, setae 6 about $1 / 2$ length of seta 3 , seta 71.5 times shorter than seta 6 , other setae very short. Setae $1-5$ plumose, seta 6 with three rows of hard setules in distal part, seta 7 with thin setules on its distal part. Distal endite with 3 setae, two distalmost members scraping, slender, sharp, with denticles in distal part; short bottle-shaped sensillum located between their bases; basal most seta flattened, as long as basal scraping setae, bilaterally armed with long setules. Basal endite with 4 plumose setae increasing in size basally. Four pointed soft setae increasing in size basally, a small bottle-shaped sensillum near the distalmost seta. Distal armature of gnathobase with four 


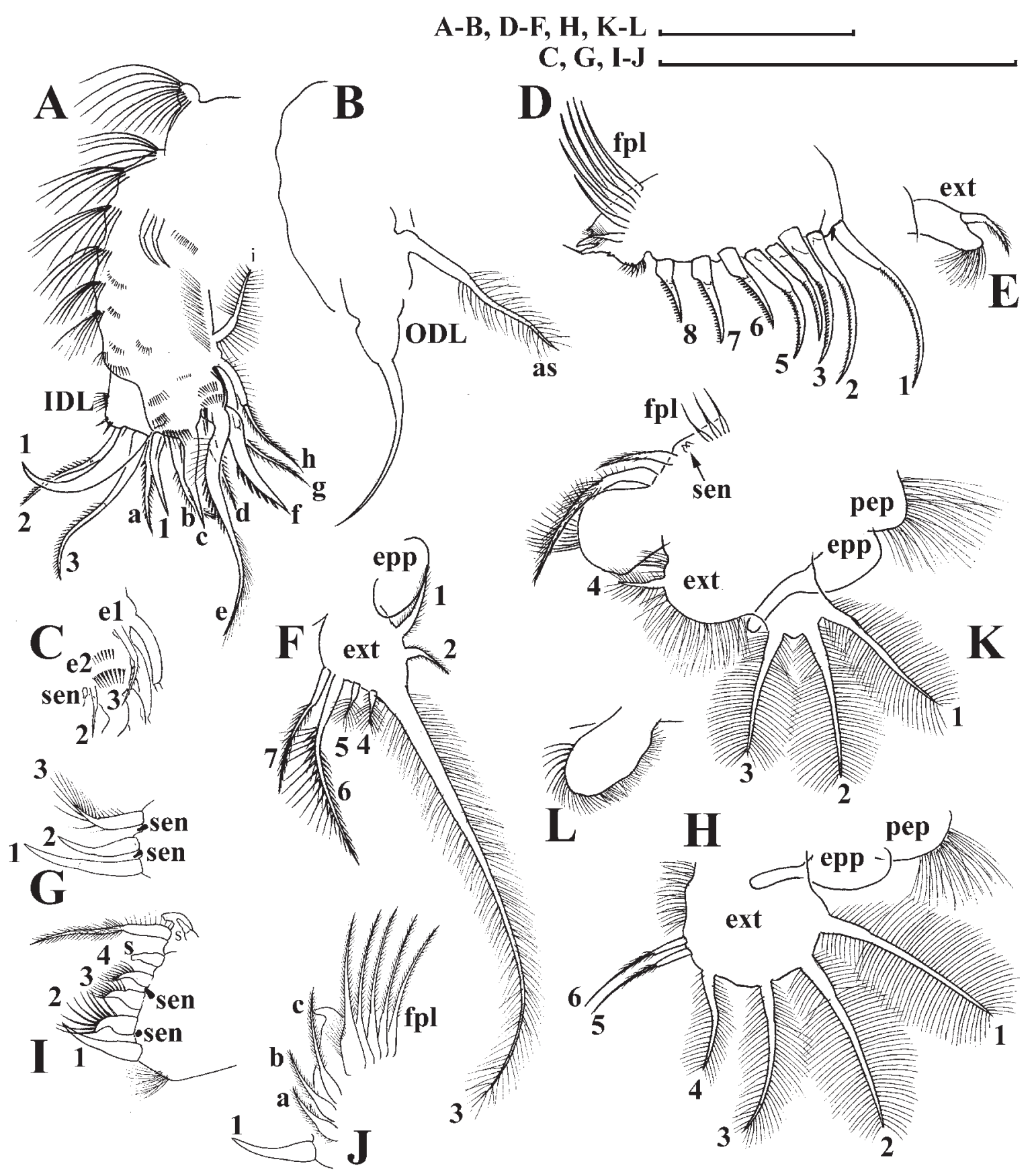

Fig. 9. Thoracic limbs of parthenogenetic female of Alona cf. affinis from River Kharpy, $15 \mathrm{~km}$ from its mouth, locality 19. A - limb I, inner view; B — its distal portion; C - a portion of limb corm; D — limb II; E — its exopodite; F — exopodite of limb III; G — innerdistal portion of limb III; H - exopodite of limb IV; I — inner-distal portion of limb IV, inner view; J — its outer view; K — limb V; L — limb VI. Scale bars: $0.1 \mathrm{~mm}$.

Рис. 9. Торакоподы партеногенетической самки Alona cf. affinis из реки Харпи 15 км вверх от устья, точки 19. А — торакопод I, вид изнутри; В - его дистальная часть; C — часть основания торакопода; D — торакопод II; E — его экхоподит; F — экзоподит торакопода III; G — внутренняя дистальная часть торакопода III; H — экзоподит IV; I — внутренняя дистальная часть торакопода IV, вид изнутри; J — вид снаружи; K — торакопод V; L — торакопод VI. Масштабная линейка: 0,1 мм.

elements; the first one elongated, narrowing distally sensillum, second strongly geniculated seta, third and fourth - spines. Filter plate III with seven setae.

Limb IV (Fig. 9H-J) with setulated pre-epipodite; epipodite oval, with a finger-like projection shorter than exopodite itself. Exopodite rounded, with six setae. Seta 1 and 2 being longest, equal in length; seta 3 slightly shorter, bending toward inner portion of limb; seta 4 about $2 / 3$ length of seta 1 , bending toward inner portion of limb; setae 5-6 subequal in length, slightly 


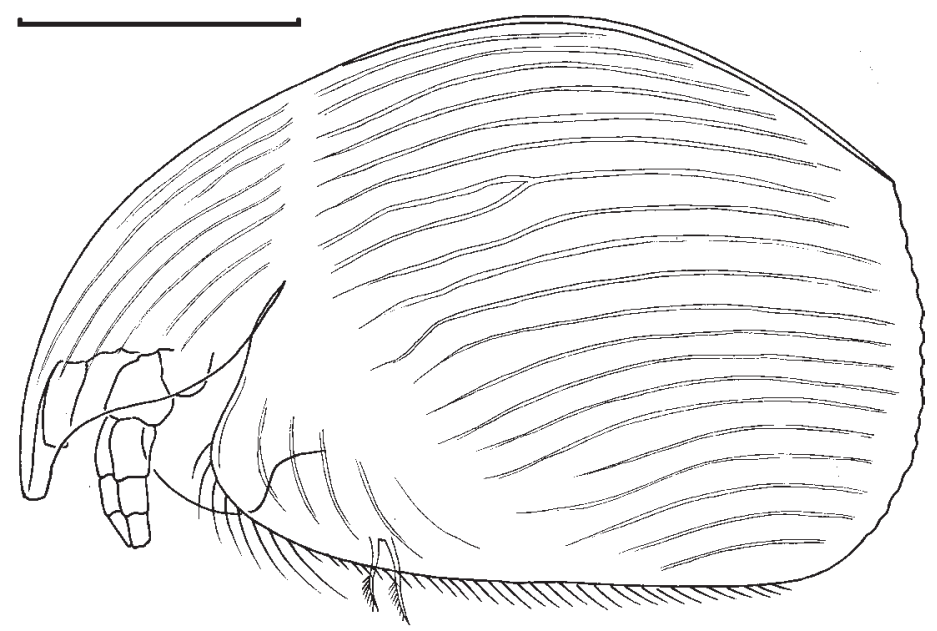

Fig. 10. General view of exuvium of parthenogenetic female of Coronatella trachystriata from Lake Bolon' about $300 \mathrm{~m}$ from the shore, locality 2. Scale bar: $0.1 \mathrm{~mm}$.

Рис. 10. Общий вид экзувиума партеногенетической самки Coronatella trachystriata из озера Болонь, в примерно 300 м от берега, точки 2. Масштабная линейка: 0,1 мм.

shorter than seta 4. Setae 1-4 plumose, setae 5-6 with short setules. Inner portion of limb IV with four setae and narrowing distally sensillum. Scraping seta slender, three flaming-torch seta decreasing in size basally, with 7-9 long setules each. Small sensillum between the base of middle and basal flaming-torch setae. Three soft setae slightly increasing in size basally. Gnathobase with one long 2-segmented setae, a small hillock distally and a sensillum. Filter plate IV with five setae.

Limb V (Fig. 9K) with setulated preepipodite; epipodite oval, with a finger-like projection as long as epipodite itself. Exopodite divided into two lobes, with four plumose setae: setae 1-3 long, subequal in length; seta 4 three times shorter. Inner lobe broad, rounded with setulated inner margin. At inner face, two setae densely setulated in distal part, one of them very long, slightly longer than exopodite setae, the other two times shorter. Filter plate V with three setae, two broad sensillum-like structures between inner face setae and filter plate.

Limb VI (Fig. 9L) as elongated oval lobe with setulated margin.

Length of adult female $0.73-0.92 \mathrm{~mm}$.

Ephippial female and male. Not found.

Comments. The representatives of the studied population differ from Eurasian populations of $A$. affinis s. str. [Sinev, 1997; Alonso, 1996; Hudec, 2010] in two minor characters of their thoracic limbs: (1) scraper 4 of limb II is significantly shorter than scapers 3 and 5 and (2) the main sensillum of inner portion of limb IV is elongated whereas it is bottle-shaped in typical $A$. affinis. All studied specimens have some denticles on postero-ventral corner of valves. According to Sinev [1997], specimens of Alona affinis with denticles on posteroventral angle represent a species variety. Thus, the conspecificity of Lake Bolon's population with Alona affinis s.str. seems doubtful.
Coronatella trachystriata (Chen, Zhang et Liu, 1994) Fig. 10.

Body low oval, strongly compressed laterally, with maximum height at body middle. Dorsal margin of carapace convex, posterior margin strongly convex, postero-ventral angle broadly rounded, postero-dorsal angle without denticles, with numerous thin setules not organized into groups (Fig. 10). Valves with a prominent linear longitudinal sculpture. Head small, rostrum in lateral view truncated, much longer than antenna I. Antenna I typical for genus, Antenna II with antennal formula: setae 0-0-3/0-1-3; spines 1-0-1/0-0-1. Limb I with IDL having two setae, seta 1 absent. Seta 3 large and thick, with long, thick spinules; seta 2 two times thinner and 1.5 times shorter than seta 3, also armed with long, thick spinules.

Comments. Only a single exuvium (without postabdomen) was found, nevertheless this permits confident identification of this taxon. This is a rare Far Eastern taxon found to date in China [Chen et al., 1994], Far East of Russia [Kotov et al., 2011a] and on Jeju Island (South Korea) [Kotov et al., 2018]. Our record is only the second of $C$. trachystriata in Russia.

\section{Subclass Copepoda Milne-Edwards, 1840}

Order Calanoida Sars, 1903

Family Temoridae Giesbrecht, 1893

Heterocope soldatovi Rylov, 1922 Fig. 11A-D.

Female. Prosome narrow, the greatest width in cephalosome, which is almost equal in length to thoracic somites. Urosome long; genital double somite almost the same width along the entire length (Fig. 11A). 


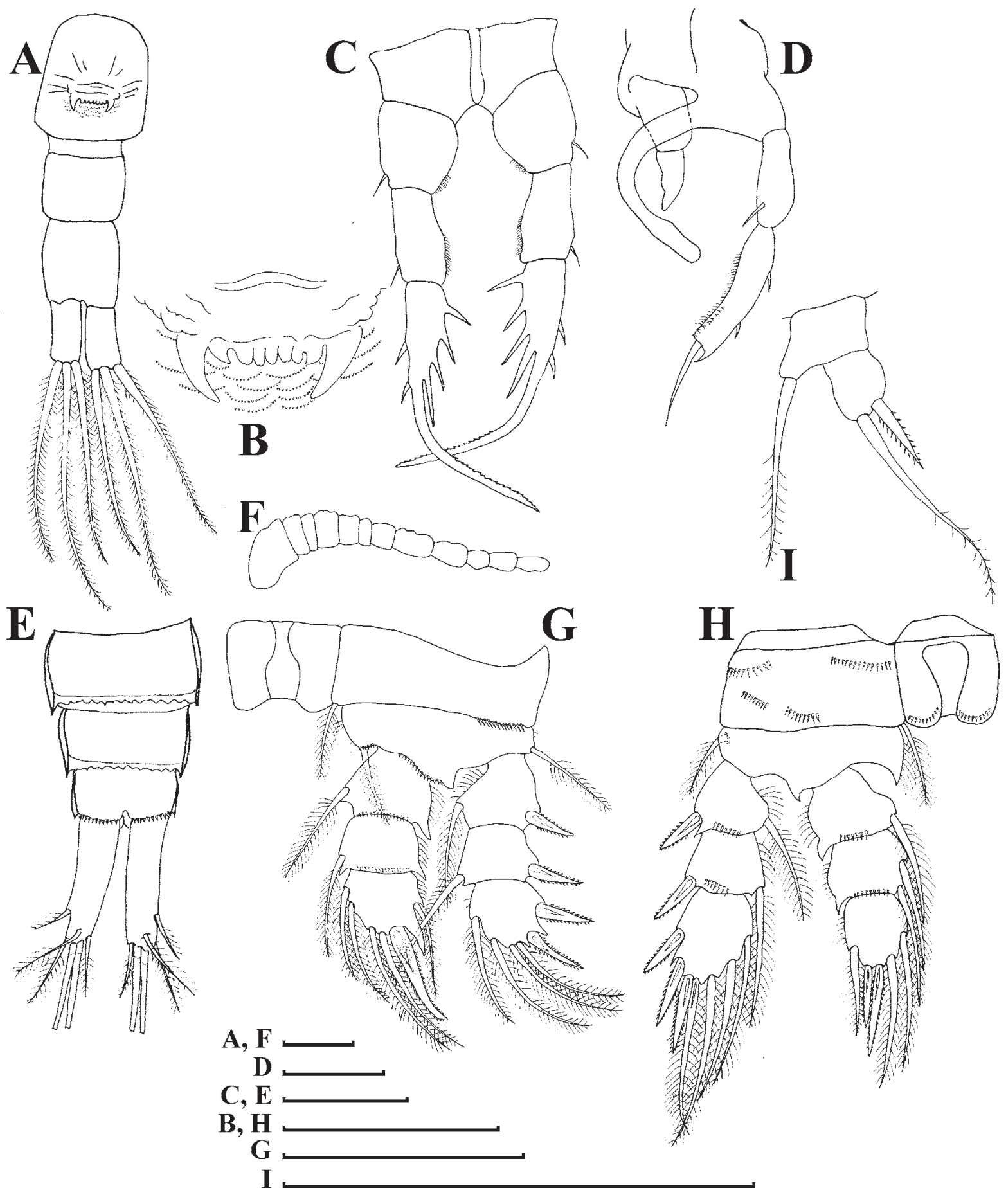

Fig. 11. Heterocope soldatovi from Lake Bolon about $300 \mathrm{~m}$ from the shore, locality 2 (A-D) and Diacyclops crassicaudis from River Simmy at Cheremshiniy Kordon, locality 13 (E-I). A — female, urosome; B - gonoporal plate; C — legs V; D — male, legs V; E female, caudal rami; F — antenna I; G — leg I; H — leg IV; I — leg V. Scale bar: $0.1 \mathrm{~mm}$.

Рис. 11. Heterocope soldatovi из озера Болонь приблизительно в 300 м от берега, точки 2 (A-D) и Diacyclops crassicaudis из Реки Симми у Черемшинного кордона, точки 13 (E-I). А — уросома самки; В — гонопорная пластинка; C — торакопод V; D самец, торакопод V; Е — самка, каудальные ветви; F — антенна I; G — торакопод I; H — торакопод IV; I — торакопод V. Масштабная линейка: 0,1 мм. 
Gonoporal plate with two large, curved tooth-like processes with short blunt lobes between them (Fig. 11B). Surface of genital double somite covered with rows of curved spinules. Caudal rami slightly shorter than anal somite. Antenna I reaches anterior margin of caudal rami. Legs V uniramous (Fig. 11C). Inner side of its basis convex, with a row of fine setae on posterior margin; first exopod segment with short outer spine and inner row of fine setae; second exopod segment with four inner spiniform processes equal in size, two outer short spines, a single long, curved apical process with a row of small spines in terminal half.

Male. Armature of all swimming legs symmetrical. Legs V uniramous, asymmetrical. Exopod of right leg $\mathrm{V}$ bi-segmented, without a specific armature (Fig. 11D). Basal segment of left leg $\mathrm{V}$ with a long inner process; first exopod segment long and slightly curved, with spine on inner posterior margin; second exopod segment longer, with two outer spines, a row of fine setae on inner margin, with one small and one long apical spines, with inner posterior lateral row of 7-9 small spines. Size in our material: female $2.3-2.4 \mathrm{~mm}$, male $2.0-2.2 \mathrm{~mm}$.

Comments. The species is an endemic of the Russian Far East. Earlier H. soldatovi was recorded from the lower reaches of the Amur River [Borutsky, 1952b], shallow water bodies of the Primorsky Krai [Smirnov, 1929], the Ussuri River, the channel from Lake Lebehe to Lake Khanka [Rylov, 1933], and Gassi Lake [Yavorskaya, 2018]. Probably this species will be found in the north-east of China.

Order Cyclopoida Burmeister, 1834

Family Cyclopidae Rafinesque, 1815

Diacyclops crassicaudis (Sars, 1863) Fig. 11E-I.

Female. Body relatively slender. Posterior margin of the last prosome somite prominently protrudes. Genital double-somite wide, its length approximately equal to width, seminal receptacle wide. Caudal rami about 4.0-4.2 times as long as wide, slightly divergent; lateral setae attached at the beginning of posterior quarter of caudal rami; outer terminal setae longer than inner terminal setae (Fig. 11E). Antenna I 12-segmented, reaching posterior margin of cephalothorax (Fig. 11F). Exopodites and endopodites of legs I to 4 3-segmented (Fig. 11G-H). Length of the third segment of legs IV endopod approximately equal to its width. Of two apical spines of this segment, inner one $1 / 3$ longer than the outer (Fig. 11H). Caudal side of coxopodite of legs IV with four spine groups A-B-C-E [Alekseev, Defaye, 2011]. Apical spine of leg V exopodal segment slightly longer than the segment (Fig. 11I). Size in our material $0.74-0.75 \mathrm{~mm}$.

Comments. D. crassicaudis is recorded in water bodies of Far East for the first time. This species is regarded to be widely distributed from the Arctic to subtropical latitudes [Rylov, 1948; Fefilova, 2015]. Two specimens were found in the River Simmy near Cheremshiniy Kordon and are similar to those found in more northern regions [Novichkova, Chertoprud, 2017; Dimante-Deimantovica et al., 2018].

\section{Biodiversity analysis}

Our analysis of the Copepoda biodiversity (Fig. 12) reveals that the group is comparatively better studied: both sample-based rarefaction curve and the best species richness estimator reach the same plateau at 13 taxa. In contrast, neither sample-based rarefaction curve nor the best species richness estimator reaches a plateau for the Cladocera. Therefore, the cladoceran biodiversity of the Lake Bolon basin is still incompletely studied, but nevertheless some important conclusions could be made. Finally, among the taxa revealed here, either no obvious dominant species or dominant species complexes were obtained.

\section{Discussion}

Cladocerans of the Far East of Russia are studied in general better as compared with the copepods, and no new records of the cladocerans from this region are made here as compared to the list of Kotov [2016]. In Table 2 we subdivided them into the main faunistic complexes as it was made by Kotov [2016], but even more roughly. Most our taxa belong to an artificial "complex" of the species which are widely distributed in Eurasia (or even in Holarctic), or regarded to be "cosmopolitan". Each such taxon apparently needs an accurate global taxonomic revision keeping in mind "Frey"s non-cosmopolitanism paradigm" of cladoceran biogeography [Frey, 1973, 1982]. We are sure that many such "taxa" are in reality species complexes which could not be discriminated at recent level of morphology-based taxonomy. For instance, it was demonstrated as a result of two pan-Palaearctic phylogeographic studies that "Chydorus sphaericus" is a group of several (at least three) taxa with different distribution ranges, and Chydorus sphaericus s.str. does not occur in the Russian Far East [Belyaeva, Taylor, 2009; Kotov et al., 2016]. Also there is evidence of the existence of other North Eurasian cryptic species groups: Diaphanosoma brachyurum s.1. [Korovchinsky, 2004; Korovchinsky, Sheveleva, 2009], Moina micrura [Bekker et al., 2016], Polyphemus pediculus [Xu et al., 2009], and some other taxa.

In some other cases, genetic data confirm the conspecificity of populations from Europe and Far East as it is the case of Eurycercus macracanthus, Daphnia sinensis, Moina macrocopa [Bekker et al., 2012, 2016; Popova et al., 2016] or some clades of P. pediculus [Xu et al., 2009]. Therefore, both the «non-cosmopolitanism" paradigm is not universal and taxonomic status and geographical range of all poorly studied taxa need a revision. This makes premature any global conclusions on the cladoceran biogeography and status of the 

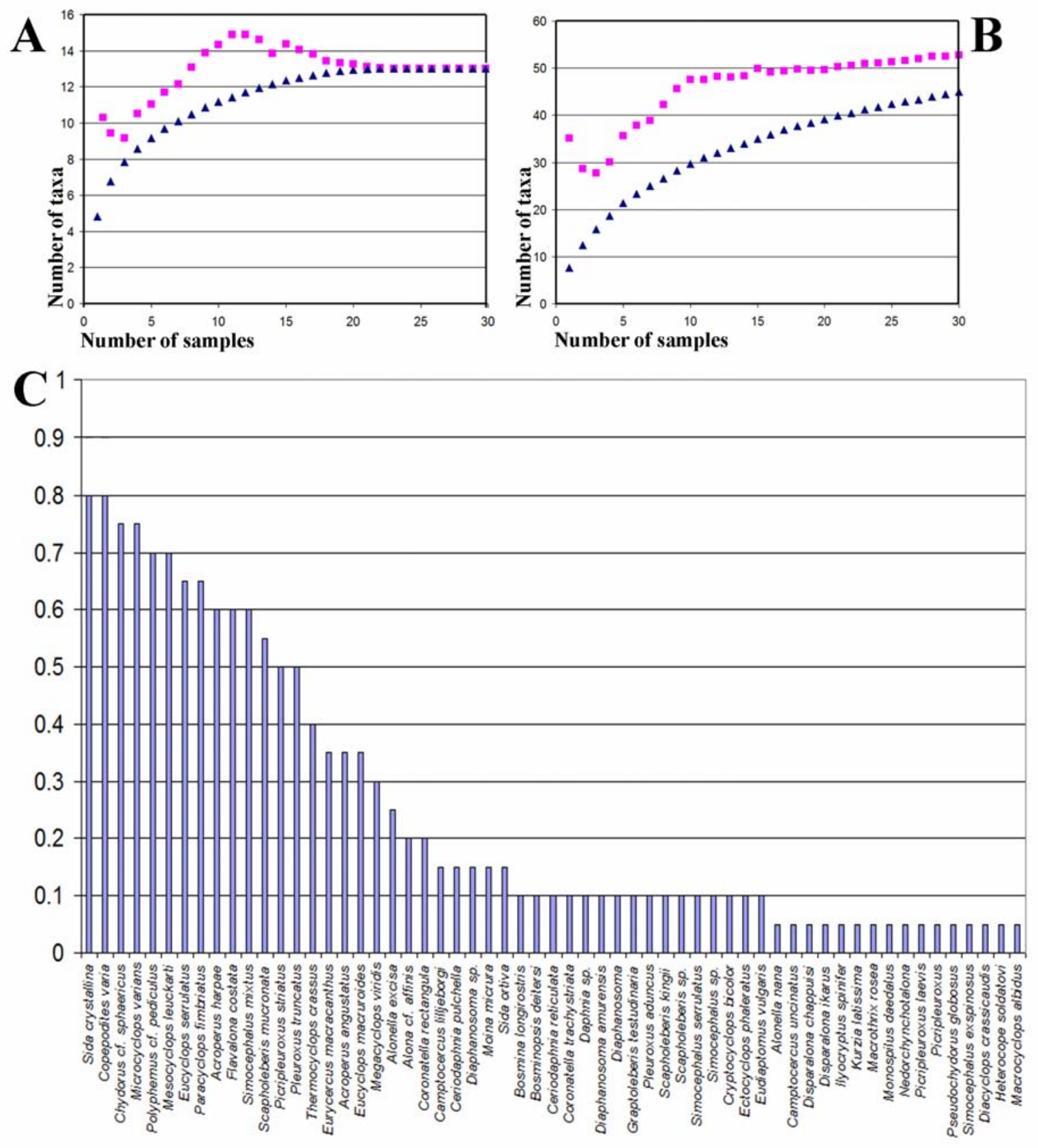

Fig. 12. Empiric and estimated number of taxa of Copepoda (A), Cladocera (B) and portion of water bodies (among 20) where each taxon was recorded (C). Triangles - sample-based rarefaction curve; quadrates - best species richness estimator (Chao 2 for Copepoda, Chao 1 for Cladocera).

Рис. 12. Эмпирическое и ожидаемое число таксонов Copepoda (A), Cladocera (B) и доля водоемов (из 20), в которой найден каждый таксон (С). Треугольники - эмпирическая кривая разряжения, квадраты — таковая согласно лучшей модели оценки биоразнообразия (Chao 2 для Copepoda, Chao 1 для Cladocera).

Far Eastern cladoceran fauna. Here we just confirm at morphological level that Sida crystallina, Acroperus harpae, A. angustatus, Camptocercus lilljeborgi, and Kurzia latissima are present in the Far East, and their females from the Far East and in Europe are morphologically undistinguishable. However, for better confidence we need to compare males because they are more valuable for differentiation of close species (see Popova et al., 2016; Smirnov, Kotov, 2018).

At the same time, other types of the cladoceran distribution ranges are remarkable and could be preliminarily analyzed. The taxa widely distributed in Eastern Eurasia, but absent in Western Eurasia, have been known long ago [Smirnov, 1971; Korovchinsky, 1979]. 
Table 2. Taxa recorded in twenty water bodies from the Lake Bolon basin.END - endemic of Far East; EUR — widely distributed in Eurasia or even in Holarctic and needs a revision; EEUR - distributed in eastern portion of Eurasia; COS — so-called "cosmopolitan" taxon needs a revision; THE — taxon of southern thermophylous complex for which the Amur basin is its northernmost region of occurrence.

\begin{tabular}{|c|c|c|c|c|c|c|c|c|c|}
\hline Taxon & 1 & 2 & 3 & 4 & 5 & 6 & 7 & 8 & 9 \\
\hline \multicolumn{10}{|l|}{ Cladocera } \\
\hline Acroperus angustatus Sars, 1863 & 0 & 0 & 0 & 0 & 1 & 0 & 0 & 0 & 0 \\
\hline Acroperus harpae (Baird, 1834) & 0 & 1 & 0 & 0 & 1 & 1 & 1 & 1 & 0 \\
\hline Alona cf. affinis (Leydig, 1860) & 0 & 0 & 0 & 0 & 0 & 0 & 0 & 0 & 0 \\
\hline Alonella excisa (Fischer, 1854) & 0 & 0 & 0 & 0 & 1 & 1 & 1 & 0 & 0 \\
\hline $\begin{array}{l}\text { Alonella nana (Baird, 1843) } \\
\text { Bosmina longirostris (O.F. Müller, }\end{array}$ & 0 & 0 & 0 & 0 & 1 & 0 & 0 & 0 & 0 \\
\hline 1776) & 0 & 1 & 0 & 0 & 0 & 0 & 0 & 0 & 0 \\
\hline $\begin{array}{l}\text { Bosminopsis deitersi Richard, } \\
1895\end{array}$ & 0 & 1 & 0 & 0 & 0 & 0 & 0 & 0 & 0 \\
\hline $\begin{array}{l}\text { Camptocercus lilljeborgi Schödler, } \\
1862\end{array}$ & 0 & 0 & 0 & 0 & 0 & 0 & 0 & 0 & 0 \\
\hline $\begin{array}{l}\text { Camptocercus uncinatus Smirnov, } \\
1971\end{array}$ & 0 & 0 & 0 & 0 & 0 & 0 & 0 & 0 & 0 \\
\hline $\begin{array}{l}\text { Ceriodaphnia pulchella Sars, } 1862 \\
\text { Ceriodaphnia reticulata (Jurine, } \\
1820 \text { ) }\end{array}$ & 0 & 0 & 0 & 0 & 0 & 0 & 0 & 0 & 0 \\
\hline $\begin{array}{l}\text { Chydorus cf. sphaericus (O.F. } \\
\text { Müller, 1776) }\end{array}$ & 1 & 1 & 0 & 1 & 1 & 1 & 1 & 0 & 0 \\
\hline $\begin{array}{l}\text { Coronatella rectangula (Sars, } \\
1862 \text { ) }\end{array}$ & 0 & 1 & 0 & 1 & 0 & 0 & 0 & 0 & 0 \\
\hline $\begin{array}{l}\text { Coronatella trachystriata (Chen, } \\
\text { Zhang et Liu, 1994) }\end{array}$ & 0 & 1 & 0 & 0 & 0 & 0 & 0 & 0 & 0 \\
\hline $\begin{array}{l}\text { Daphnia } \text { sp. } \\
\text { Diaphanosoma amurensis }\end{array}$ & 0 & 1 & 0 & 0 & 0 & 0 & 0 & 0 & 1 \\
\hline Korovchinsky et Sheveleva, 2009 & 0 & 0 & 0 & 0 & 0 & 0 & 0 & 0 & 0 \\
\hline $\begin{array}{l}\text { Diaphanosoma sp. } \\
\text { Diaphanosoma macrophtalma } \\
\text { Korovchinsky et Mirabdullaev, } \\
1995\end{array}$ & 0 & 0 & 0 & 0 & 0 & 1 & 1 & 0 & 0 \\
\hline $\begin{array}{l}\text { Disparalona chappuisi (Brehm, } \\
\text { 1931) }\end{array}$ & 0 & 0 & 0 & 0 & 0 & 0 & 0 & 0 & 0 \\
\hline $\begin{array}{l}\text { Disparalona ikarus Kotov et } \\
\text { Sinev, } 2011\end{array}$ & 0 & 0 & 0 & 0 & 0 & 0 & 0 & 0 & 0 \\
\hline $\begin{array}{l}\text { Eurycercus macracanthus Frey, } \\
1973\end{array}$ & 0 & 0 & 0 & 0 & 1 & 0 & 0 & 0 & 0 \\
\hline Flavalona costata (Sars, 1862) & 1 & 1 & 0 & 1 & 1 & 1 & 0 & 0 & 0 \\
\hline $\begin{array}{l}\text { Graptoleberis testudinaria } \\
\text { (Fischer, 1848) }\end{array}$ & 0 & 0 & 0 & 0 & 0 & 0 & 0 & 0 & 0 \\
\hline Ilyocryptus spinifer Herrick, 1882 & 0 & 0 & 0 & 0 & 0 & 0 & 0 & 0 & 0 \\
\hline Kurzia latissima (Kurz, 1875) & 0 & 0 & 0 & 0 & 0 & 0 & 0 & 0 & 0 \\
\hline Macrothrix rosea Jurine, 1820 & 0 & 0 & 0 & 0 & 0 & 0 & 0 & 0 & 0 \\
\hline Moina micrura Kurz, 1875 & 0 & 0 & 1 & 0 & 0 & 0 & 0 & 1 & 1 \\
\hline
\end{tabular}


Таблица 2. Таксоны, найденные в 20 водоемах в бассейне Озера Болонь. END - эндемик Дальнего Востока; EUR таксон, широко распространен а Евразии или даже в Голарктике, который должен быть подвергнут ревизии; EEUR - распространен в восточной части Евразии; COS — так называемый «космополит», который должен быть подвергнут ревизии; ТНЕ - таксон южного теплолюбивого комплекса, для которого бассейн Амура — наиболее северный регион обитания.

\begin{tabular}{|c|c|c|c|c|c|c|c|c|c|c|c|c|}
\hline 10 & 11 & 12 & 13 & 14 & 15 & 16 & 17 & 18 & 19 & 20 & $\begin{array}{l}\text { Total no. of } \\
\text { localities }\end{array}$ & $\begin{array}{l}\text { Faunis } \\
\text { comple }\end{array}$ \\
\hline 1 & 0 & 1 & 1 & 1 & 1 & 0 & 0 & 0 & 1 & 0 & 7 & EUR \\
\hline 1 & 1 & 0 & 1 & 0 & 0 & 1 & 1 & 1 & 1 & 0 & 12 & EUR \\
\hline 0 & 0 & 0 & 1 & 0 & 0 & 0 & 0 & 1 & 1 & 1 & 4 & EUR \\
\hline 0 & 0 & 0 & 0 & 0 & 0 & 0 & 0 & 1 & 1 & 0 & 5 & COS \\
\hline 0 & 0 & 0 & 0 & 0 & 0 & 0 & 0 & 0 & 0 & 0 & 1 & $\cos$ \\
\hline 0 & 1 & 0 & 0 & 0 & 0 & 0 & 0 & 0 & 0 & 0 & 2 & $\cos$ \\
\hline 0 & 1 & 0 & 0 & 0 & 0 & 0 & 0 & 0 & 0 & 0 & 2 & THE \\
\hline 0 & 0 & 0 & 0 & 1 & 0 & 0 & 0 & 1 & 1 & 0 & 3 & EUR \\
\hline 0 & 0 & 0 & 0 & 0 & 0 & 0 & 0 & 0 & 1 & 0 & 1 & EEUR \\
\hline 0 & 1 & 0 & 1 & 0 & 0 & 0 & 1 & 0 & 0 & 0 & 3 & COS \\
\hline 0 & 0 & 0 & 0 & 0 & 0 & 0 & 0 & 0 & 0 & 0 & 2 & $\cos$ \\
\hline 1 & 1 & 1 & 1 & 1 & 1 & 1 & 1 & 0 & 1 & 0 & 15 & $\cos$ \\
\hline 0 & 1 & 0 & 0 & 0 & 0 & 0 & 0 & 0 & 1 & 0 & 4 & COS \\
\hline 0 & 0 & 0 & 0 & 0 & 0 & 0 & 0 & 0 & 0 & 0 & 2 & END \\
\hline 0 & 0 & 0 & 0 & 0 & 0 & 0 & 0 & 0 & 0 & 0 & 2 & $?$ \\
\hline 0 & 0 & 0 & 1 & 0 & 0 & 0 & 1 & 0 & 0 & 0 & 2 & EEUR \\
\hline 0 & 1 & 0 & 0 & 0 & 0 & 0 & 0 & 0 & 0 & 0 & 3 & $?$ \\
\hline 1 & 0 & 0 & 0 & 0 & 0 & 0 & 0 & 0 & 0 & 0 & 2 & EUR \\
\hline 0 & 0 & 0 & 1 & 0 & 0 & 0 & 0 & 0 & 0 & 0 & 1 & THE \\
\hline 0 & 0 & 1 & 0 & 0 & 0 & 0 & 0 & 0 & 0 & 0 & 1 & END \\
\hline 0 & 1 & 0 & 0 & 0 & 1 & 1 & 0 & 1 & 1 & 1 & 7 & EUR \\
\hline 0 & 1 & 1 & 1 & 1 & 0 & 0 & 1 & 1 & 1 & 0 & 12 & COS \\
\hline 0 & 0 & 0 & 0 & 0 & 0 & 1 & 0 & 1 & 0 & 0 & 2 & $\cos$ \\
\hline 0 & 0 & 0 & 0 & 1 & 0 & 0 & 0 & 0 & 0 & 0 & 1 & THE \\
\hline 1 & 0 & 0 & 0 & 0 & 0 & 0 & 0 & 0 & 0 & 0 & 1 & EUR \\
\hline 0 & 0 & 0 & 1 & 0 & 0 & 0 & 0 & 0 & 0 & 0 & 1 & EUR \\
\hline 0 & 0 & 0 & 0 & 0 & 0 & 0 & 0 & 0 & 0 & 0 & 3 & COS \\
\hline
\end{tabular}




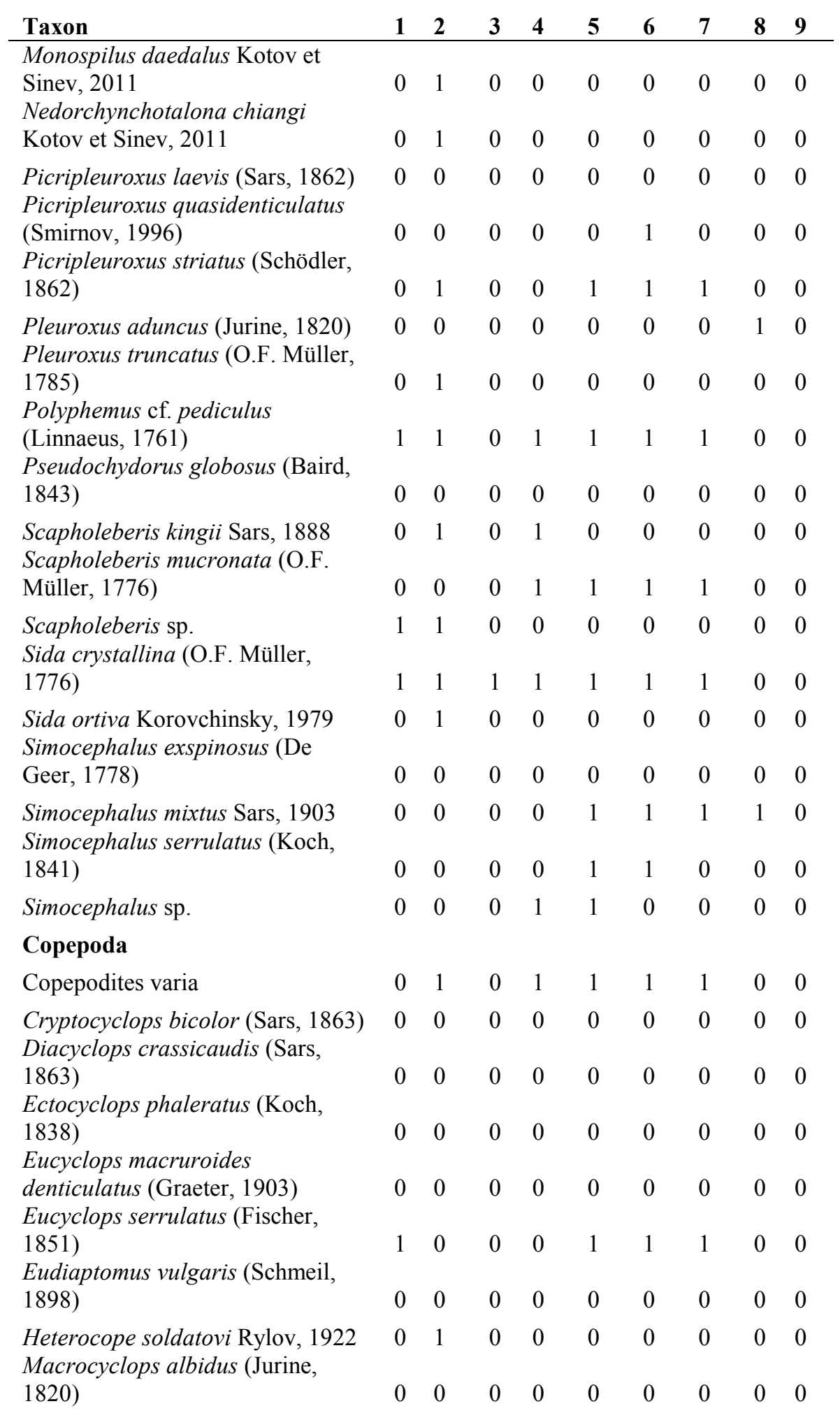




\begin{tabular}{|c|c|c|c|c|c|c|c|c|c|c|c|c|}
\hline 10 & 11 & 12 & 13 & 14 & 15 & 16 & 17 & 18 & 19 & 20 & $\begin{array}{l}\text { Total no. of } \\
\text { localities }\end{array}$ & $\begin{array}{l}\text { Faunistic } \\
\text { complex }\end{array}$ \\
\hline 0 & 0 & 0 & 0 & 0 & 0 & 0 & 0 & 0 & 0 & 0 & 1 & END \\
\hline 0 & 0 & 0 & 0 & 0 & 0 & 0 & 0 & 0 & 0 & 0 & 1 & END \\
\hline 0 & 0 & 0 & 0 & 0 & 0 & 0 & 0 & 1 & 0 & 0 & 1 & EUR \\
\hline 0 & 0 & 0 & 0 & 0 & 0 & 0 & 0 & 0 & 0 & 0 & 1 & THE \\
\hline 0 & 1 & 0 & 1 & 1 & 1 & 1 & 0 & 1 & 0 & 0 & 10 & EUR \\
\hline 0 & 0 & 0 & 0 & 0 & 0 & 0 & 0 & 0 & 1 & 0 & 2 & COS \\
\hline 0 & 1 & 1 & 1 & 1 & 1 & 1 & 1 & 1 & 1 & 0 & 10 & EUR \\
\hline 1 & 0 & 1 & 1 & 1 & 1 & 0 & 1 & 0 & 1 & 1 & 14 & EUR \\
\hline 0 & 0 & 0 & 0 & 0 & 0 & 0 & 0 & 1 & 0 & 0 & 1 & EUR \\
\hline 0 & 0 & 0 & 0 & 0 & 0 & 0 & 0 & 0 & 0 & 0 & 2 & THE \\
\hline 1 & 1 & 1 & 1 & 0 & 0 & 0 & 1 & 0 & 1 & 1 & 11 & EUR \\
\hline 0 & 0 & 0 & 0 & 0 & 0 & 0 & 0 & 0 & 0 & 0 & 2 & $?$ \\
\hline 1 & 1 & 0 & 1 & 1 & 1 & 1 & 1 & 1 & 1 & 0 & 16 & EUR \\
\hline 0 & 0 & 1 & 1 & 0 & 0 & 0 & 0 & 0 & 0 & 0 & 3 & EEUR \\
\hline 0 & 0 & 0 & 0 & 0 & 0 & 0 & 0 & 0 & 1 & 0 & 1 & COS \\
\hline 0 & 1 & 1 & 0 & 1 & 1 & 1 & 1 & 1 & 0 & 1 & 12 & COS \\
\hline 0 & 0 & 0 & 0 & 0 & 0 & 0 & 0 & 0 & 0 & 0 & 2 & COS \\
\hline 0 & 0 & 0 & 0 & 0 & 0 & 0 & 0 & 0 & 0 & 0 & 2 & $?$ \\
\hline 1 & 1 & 1 & 1 & 1 & 1 & 1 & 1 & 1 & 1 & 1 & 16 & \\
\hline 0 & 0 & 0 & 0 & 0 & 1 & 0 & 0 & 0 & 0 & 1 & 2 & COS \\
\hline 0 & 0 & 0 & 1 & 0 & 0 & 0 & 0 & 0 & 0 & 0 & 1 & COS \\
\hline 0 & 0 & 0 & 0 & 1 & 1 & 0 & 0 & 0 & 0 & 0 & 2 & COS \\
\hline 1 & 1 & 0 & 1 & 0 & 0 & 1 & 0 & 1 & 1 & 1 & 7 & EUR \\
\hline 1 & 1 & 1 & 1 & 1 & 1 & 1 & 1 & 0 & 1 & 0 & 13 & COS \\
\hline 0 & 0 & 0 & 0 & 0 & 0 & 0 & 1 & 1 & 0 & 0 & 2 & EUR \\
\hline 0 & 0 & 0 & 0 & 0 & 0 & 0 & 0 & 0 & 0 & 0 & 2 & END \\
\hline 0 & 0 & 0 & 1 & 0 & 0 & 0 & 0 & 0 & 0 & 0 & 1 & COS \\
\hline
\end{tabular}




\begin{tabular}{|c|c|c|c|c|c|c|c|c|c|}
\hline Taxon & 1 & 2 & 3 & 4 & 5 & 6 & 7 & 8 & 9 \\
\hline $\begin{array}{l}\text { Megacyclops viridis(Jurine, 1820) } \\
\text { Mesocyclops leuckarti (Claus, }\end{array}$ & 1 & 0 & 0 & 1 & 0 & 1 & 1 & 0 & 0 \\
\hline 1857$)$ & 1 & 1 & 0 & 1 & 1 & 1 & 1 & 0 & 0 \\
\hline $\begin{array}{l}\text { Microcyclops varians (Sars, } 1863 \text { ) } \\
\text { Paracyclops fimbriatus orientalis }\end{array}$ & 1 & 1 & 0 & 1 & 1 & 1 & 1 & 0 & 0 \\
\hline $\begin{array}{l}\text { (Alekseev, 1995) } \\
\text { Thermocyclops crassus (Fischer, }\end{array}$ & 1 & 1 & 0 & 0 & 0 & 1 & 1 & 0 & 0 \\
\hline 1853) & 0 & 0 & 0 & 1 & 0 & 0 & 0 & 0 & 0 \\
\hline Total species richness of locality & 11 & 22 & 2 & 13 & 18 & 19 & 16 & 4 & 2 \\
\hline
\end{tabular}

Based on genetic data, it was concluded that there is a main longitudinal biogeographic transitory zone between two faunistic super-complexes in the Yenisey River basin (sometimes in the Ob River basin) [Bekker et al., 2016, 2018; Kotov et al., 2016], as it was predicted earlier [Korovhinsky, 2004]. Only three cladocerans (Sida ortiva, Diaphanosoma amurensis, Camptocercus uncinatus) from Lake Bolon basin belong to the Eastern Asian complex to date, but after revisions of particular taxa such number should be strongly increased.

At least five taxa (Scapholeberis kingi, Bosminopsis deitersi, Disparalona chappuisi, Picripleuroxus quasidenticulatus, Ilyocryptus spinifer) of the Cladocera found by us belong to a thermophylous ("tropical") complex, earlier revealed in the Zeya River basin [Kotov et al., 2011a-b; Kotov, Sinev, 2011]. The number of such taxa recorded from the Far East of Russia and Korea is continuously increasing [Kotov et al., 2012; Sinev, Samoamuang, 2013; Garibian, 2017; Neretina et al., 2018]. For these taxa, the Amur River basin is an "area of penetration" sensu Korovchinsky [2004, 2006], while their "area of primary distribution" is situated in tropics and subtropics. Their appearance in Russian Far East could be a reflection of specific conditions (monsoon climate) or historical factors which need to be studied.

The most spectacular result of the last decade is a conclusion on existing of a particularly remarkable zone of the cladoceran endemism in the southern temperate / northern subtropics of the Far East as it was predicted by Korovchinsky [2004, 2006]. Such taxa are absent in more northern regions, see publications on Central Yakutia [Klimovsky et al., 2015a, b] and Magadan Area [Streletskaya, 1975a, b]. Although they are found in Korea [Kotov et al., 2012]. Some of them are known from North China [Chiang, Du, 1979], but we believe that the rest could be also found there. At the same time, they are absent in tropical SE Asia [Korovchinky, 2013; Kotov et al., 2013; Sinev, Korovchinsky, 2013]. Several taxa recorded in the Lake Bolon area apparently belong to such East Asian endemics, and our study demonstrates that they are com- mon in the Amur basin. We cannot conclude with confidence whether they are strongly associated with the Amur River basin in their northern distribution limit, or not, which has to be studied later. Smirnov \& Kotov [2018] pointed out that the chydorids from such an endemic complex demonstrate a specific Far Eastern morphological style, e.g. having lateral projections on valves.

The major part of the copepods noted in the Bolon' $\mathrm{s}$ basin belong to cosmopolitan ( 9 species) and widely distributed in Eurasia (3) species. Possible, many widespread species of copepods are actually complexes of cryptic species that are similar morphologically, in some cases genetic methods could solve the problems of cyclopoid taxonomy [Krajíèek et al., 2016; Mayor et al., 2017]. A high level of polymorphism also was recorded for some freshwater and brackishwater species of the order Harpacticoida [Schizas et al., 1999; Rocha-Olivares et al., 2001; Garlitska et al., 2012; Kochanova et al., 2018]. Diacyclops crassicaudis, which is recorded for the first time for this region, also belongs to such "cosmopolitan" taxa. Being widely distributed, it has been previously regarded as a "glacial relict", indeed, "areas of primary distribution" of this species included the tundra and taiga zones, however, some populations are also found in more southern regions (for example, North Africa and Creta) [Rylov, 1948]. In contrast, Heterocope soldatovi is an endemic of the Russian Far East. No representatives of the southern thermophylous species complex are found among the copepods.

Thus, the fauna of the Cladocera and Copepoda of the Bolon Lake Basin is diverse and specific, it includes endemics of the Far Eastern Region. The cladocerans are more speciose and heterogeneous in their type ranges as compared to the copepods in this region. Particularly, the southern thermophylous species complex is detected there only for the former group, while most copepods are cosmopolitan or widespread in Eurasia. In addition, if the fauna of copepods is adequately evaluated in the Bolon lake basin, the cladoceran species number is significantly underestimated. Further investigations of the zooplankton of the Amur River 


\begin{tabular}{lllllllllllll}
\hline $\mathbf{1 0}$ & $\mathbf{1 1}$ & $\mathbf{1 2}$ & $\mathbf{1 3}$ & $\mathbf{1 4}$ & $\mathbf{1 5}$ & $\mathbf{1 6}$ & $\mathbf{1 7}$ & $\mathbf{1 8}$ & $\mathbf{1 9}$ & $\mathbf{2 0}$ & $\begin{array}{l}\text { Total no. of } \\
\text { localities }\end{array}$ & $\begin{array}{l}\text { Faunistic } \\
\text { complex }\end{array}$ \\
\hline 0 & 0 & 0 & 1 & 0 & 0 & 0 & 0 & 0 & 0 & 1 & $\mathbf{6}$ & COS \\
1 & 1 & 1 & 1 & 0 & 1 & 1 & 1 & 0 & 1 & 0 & $\mathbf{1 4}$ & COS \\
1 & 1 & 1 & 1 & 1 & 1 & 0 & 1 & 1 & 1 & 0 & $\mathbf{1 5}$ & COS \\
0 & 1 & 1 & 1 & 0 & 1 & 1 & 1 & 1 & 1 & 1 & $\mathbf{1 3}$ & EUR \\
1 & 0 & 1 & 1 & 0 & 0 & 1 & 1 & 1 & 0 & 1 & $\mathbf{8}$ & COS \\
\hline $\mathbf{1 4}$ & $\mathbf{2 0}$ & $\mathbf{1 5}$ & $\mathbf{2 5}$ & $\mathbf{1 5}$ & $\mathbf{1 5}$ & $\mathbf{1 4}$ & $\mathbf{1 7}$ & $\mathbf{1 9}$ & $\mathbf{2 2}$ & $\mathbf{1 1}$ & & \\
\hline
\end{tabular}

Basin water bodies are necessary. Just such data will provide a basis for biogeographical analysis of the Cladocera and Copepoda of Far East fauna as a whole.

\section{Acknowledgments}

The authors are very grateful to the staff of the FSBI "Zapovednoe Priamurye" and Bolon'sky State Nature Reserve for their help in organizing the expeditionary works. Many thanks to R.J. Shiel for linguistic corrections of earlier draft and M. Roshchin for providing photos of the Bolon Lake.

This study is supported by the Russian Science Foundation (project No. 18-14-00325).

\section{References}

Alekseev V., Defaye D. 2011. Taxonomic differentiation and world geographical distribution of the Eucyclops serrulatus group (Copepoda, Cyclopidae, Eucyclopinae) // Crustaceana Monographs. Vol.16. P.41-72.

Avarijaskin L.P. 1970. [Relief] // Voprosi geografii Priamuriya Nizhnee Priamuriye. Khabarovsk: Nauka Press. P.167-174 [in Russian].

Barabanshchikov E.I. 2000. [Qualitative composition of zooplankton in the Khanka Lake] // Geokhimicheskie i ekologo-biochimicheskiye issledovaniya $v$ Priamurie. Vol.10. P.130-139. [in Russian]

Barabanshchikov E.I. 2004. [Zooplankton of the Khanka Lake. PhD Thesis]. St. Petersburg: Zoological Institute of RAS. 215 pp. [in Russian].

Barabanshchikov E.I. 2014. [Zooplankton of Ussury River basin (Primorye Territory)] // Chteniya Pamiati Vladimira Yakovlevicha Levanidova. No.6. P.78-87 [in Russian].

Barabanshchikov E.I., Kozhevnikov B.P. 1998. [Dynamics of abundance and biomass of zooplankton in the open water of the Khanka Lake] // Izvestiya TINRO. Vol.123. P.362-374 [in Russian].

Bekker E.I., Kotov A.A., Taylor D.J. 2012. A revision of the subgenus Eurycercus (Eurycercus) Baird, 1843 emend. nov. (Cladocera: Eurycercidae) in the Holarctic with the description of a new species from Alaska // Zootaxa. Vol.3206. P.1-40.

Bekker E.I., Karabanov D.P., Galimov Y.R., Kotov A.A. 2016. DNA barcoding reveals high cryptic diversity in the North Eurasian Moina species (Crustacea: Cladocera) // PLoS ONE. Vol.11. No.8. e0161737.

Bekker E.I., Karabanov D.P., Galimov Y.R., Haag C.R., Neretina T.V., Kotov A.A. 2018. Phylogeography of Daphnia magna Straus (Crustacea: Cladocera) in Northern Eurasia: Evidence for a deep longitudinal split between mitochondrial lineages // PLoS ONE. Vol.13. No.3. e0194045.

Belyaeva M., Taylor D.J. 2009. Cryptic species within the Chydorus sphaericus species complex (Crustacea: Cladocera) revealed by molecular markers and sexual stage morphology // Molecular Phylogenetics and Evolution. Vol.50. P.534-546.

Berg L.S. 1948. [Freshwater fishes of the USSR and adjacent countries. Vol.1]. M.-L.: Izdatel'stvo Akademii Naus SSSR. 468 p. [In Russian]

Borutsky E.V. 1952a. [Freshwater Harpacticoids] // Fauna SSSR. Crustacea. Vol.3. M.-L.: AN USSR Publishing. 425 p. [In Russian]

Borutsky E.V. 1952b. [Seston of Amur River and his role in feeding Amur fishes] // Trudy Amurskoy Ichthyologicheskoy Ekspeditsii 1945-1949. Vol. 3. P.141-228 [in Russian].

Borutsky E.V., Stepanova L.A., Kos M.S. 1991. [Key to identification of Calanoida from fresh waters]. St Petersburg: Nauka. 502 p. [In Russian]

Chen S.Z, Zhang E., Liu H. 1994. A new subspecies of Alona rectangula (Crustacea: Diplostraca) // Sichuan Journal of Zoology. Vol.13. No.3. P.101-102.

Chiang S.C., Du N.S. 1979. [Freshwater Cladocera. Fauna Sinica. Crustacea]. Peking: Science Press, Academia Sinica. 297 p. [In Chinese]

Colwell R.K. 2013. EstimateS, Version 9.1: Statistical Estimation of Species Richness and Shared Species from Samples (Software and User's Guide). (URL: http://viceroy.eeb.uconn.edu/ estimates/)

Dimante-Deimantovica I., Walseng B., Chertoprud E., Novichkova A. 2018. New and previously known species of Copepoda and Cladocera (Crustacea) from Svalbard, Norway - who are they and where do they come from? // Fauna Norvegica. Vol.38. P.18-29.

Fefilova E.B. 2015. [Copepods (Copepoda). Fauna of the European North-East of Russia]. Moscow: KMK Sci. Press. 319 p. [In Russian]

Frey D.G. 1973. Comparative morphology and biology of three species of Eurycercus (Chydoridae, Cladocera), with a description of Eurycercus macrocanthus sp. nov. // Internationale Revue der gesamten Hydrobiologie und Hydrographie. Vol.58. No.2. P.221-267.

Frey D.G. 1982. Questions concerning cosmopolitanism in Cladocera // Archiv für Hydrobiologie. Vol.93. No.4. P.484-502.

Frey D.G. 1986. Cladocera analysis // B.E. Berglund (ed.). Handbook of Holocene paleoecology and paleohydrology. Chichester: J.Wiley \& Sons Ltd. P.667-692.

Garibian P.G. 2017. [Nicsmirnovius eximius (Kiser 1948) (Cladocera, Chydoridae) from the Primorsky Territory: the first record of the genus from Russia] // Zoologicheskiy Zhurnal. Vol.96. No.11. P.1359-1363 [in Russian].

Garlitska L., Neretina T., Schepetov D., Mugue N., De Troch M., Baguley J.G., Azovsky A. 2012. Cryptic diversity of the 'cos- 
mopolitan' harpacticoid copepod Nannopus palustris: genetic and morphological evidence // Molecular Ecology. Vol.21. P.5336-5347.

Grigoriev A.A. (ed.). 1964. [Brief Geographical Encyclopedia. Vol.4]. M.: Sovetskaya Entsiklopedia. 448 pp. [In Russian]

Hudec I. 2010. [Anomopoda, Ctenopoda, Haplopoda, Onychopoda (Crustacea: Branchiopoda)]. Fauna Slovenska III. Bratislava: VEDA. 496 pp. [In Slovak]

Khachina G.A. 1948. [The microflora of the Bolon Lake in connection with nutrition of the silver carp] // Izvestija TINRO. P.187219 [in Russian].

Klimovsky A.I., Bekker E.I., Korovchinsky N.M., Kotov À.À. 2015. [Cladocera (Crustacea, Branchiopoda) of Central Yakutia 1. Some representatives of the families Sididae, Daphniidae and Ophryoxidae] // Zoologicheskiy Zhurnal. Vol.94. No.8. P.882898 [in Russian].

Klimovsky A.I., Bekker E.I., Sinev A.Y., Korovchinsky N.M., Smirnov N.N., Kotov A.A. 2015. [Cladocera (Crustacea, Branchiopoda) of Central Yakutia. 4. Taxonomical-faunistic and zoogeographical analysis] // Zoologicheskiy Zhurnal. Vol.94. No.12. P.1367-1378 [in Russian].

Kochanova E.S., Fefilova E.B., Sukhikh N.M., Velegzhaninov I.O., Shadrin D.M., Pylina Y.I., Alekseev V.R. 2018. Morphological and molecular-genetic polymorphism of Canthocamptus staphylinus Jurine (Harpacticoida, Copepoda, Crustacea) // Inland Water Biology. Vol.11. No.2. P.111-123.

Korovchinsky N.M. 1979. [On intraspecific taxonomy of Sida crystallina (Crustacea, Cladocera) of Holarctic] // Zoologicheskiy Zhurnal. Vol.58. No.12. P.1778-1789 [in Russian].

Korovchinsky N.M. 2000. Redescription of Diaphanosoma dubium Manuilova, 1964 (Branchiopoda: Ctenopoda: Sididae) and description of a new related species // Hydrobiologia. Vol.441. P.73-92.

Korovchinsky N.M., 2004. [Cladocerans of the order Ctenopoda of the world fauna (morphology, systematics, ecology, biogeography)]. Moscow: KMK Sci. Press. 410 pp. [In Russian]

Korovchinsky N.M. 2006. The Cladocera (Crustacea: Branchiopoda) as a relict group // Zoological Journal of the Linnean Society. Vol.147. P.109-124.

Korovchinsky N.M. 2009. The genus Leptodora Lilljeborg (Crustacea: Branchiopoda: Cladocera) is not monotypic: description of a new species from the Amur River basin (Far East of Russia) // Zootaxa. Vol.2120. P.39-52.

Korovchinsky N.M. 2010. A taxonomic revision of Pseudosida szalayi Daday, 1898 (Crustacea: Cladocera: Sididae) over its Asian range, with focus on the northernmost populations first recorded from the Amur River basin (Far East of Russia) // Zootaxa. Vol.2345. P.1-18

Korovchinsky N.M., 2013. Cladocera (Crustacea: Branchiopoda) of South East Asia: history of exploration, taxon richness and notes on zoogeography // Journal of Limnology. Vol.72. No.s2. P.109-124.

Korovchinsky N.M. 2014. Redescription of Limnosida frontosa Sars, 1862 (Crustacea: Cladocera: Sididae), with evidence of possible incipient species differentiation // Zootaxa. Vol.3764. P.61-80.

Korovchinsky N.M. 2018. Cladocera: Ctenopoda: Families Sididae, Holopediidae \& Pseudopenilidae (Branchiopoda: Cladocera) // Identification Guides to the Plankton and Benthos of Inland Waters. Vol.27. P.1-203.

Korovchinsky N.M., Boikova O.S. 2008. Study of the external morphology of Leptodora kindtii (Focke, 1844) (Crustacea: Branchiopoda: Haplopoda), with notes on its relation to $\mathrm{Cla}-$ docera and on conspecificity of populations of the species over the Eurasian range // Journal of Natural History. Vol.42. P.28252863.

Korovchinsky N.M., Sheveleva N.G. 2009. One new and one rare species of the genus Diaphanosoma Fischer 1850 (Crustacea, Cladocera, Sididae) from the Amur River basin // Zoologicheskiy Zhurnal. Vol.88. No.3. P.289-299 [in Russian]

Kotov A.A. 2013. [Morphology and phylogeny of the Anomopoda (Crustacea: Cladocera)]. M.: KMK Sci. Press. 638 p. [In Russian]
Kotov A.A. 2016. [Faunistic complexes of the Cladocera (Crustacea, Branchiopoda) of Eastern Siberia and Far East of Russia]. Zoologicheskiy Zhurnal. Vol.95. No.7. P.748-768 [in Russian].

Kotov A.A., Ishida S., Taylor D.J. 2006. A new species in the Daphnia curvirostris (Crustacea: Cladocera) complex from the eastern Palearctic with molecular phylogenetic evidence for the independent origin of neckteeth // Journal of Plankton Research. Vol.28. P.1067-1079.

Kotov A.A., Jeong H.J., Lee W. 2012. Cladocera (Crustacea: Branchiopoda) of the south-east of the Korean Peninsula, with twenty new records for Korea // Zootaxa. Vol.3368. P.50-90.

Kotov A.A., Korovchinsky N.M., Sinev A.Yu., Smirnov N.N., 2011a. [Cladocera (Crustacea, Branchiopoda) of the Zeya basin (Amurskaya Area, Russian Federation). 3. Systematic-faunistic and zoogeographic analysis] // Zoologichesky Zhurnal. Vol.90. P.402-411 [in Russian].

Kotov A.A., Sinev A.Yu. 2011. [Cladocera (Crustacea, Branchiopoda) of the Zeya basin (Amurskaya Area, Russian Federation). 2. Descriptions of new taxa] // Zoologichesky Zhurnal. Vol.90. P.272-284 [in Russian].

Kotov A.A., Sinev A.Y., Garibian P.G., Neretina A.N., Jeong H.G., Lee W., Chae K.S., Min G.S. 2018. Recent progress in studies of the Cladocera (Crustacea: Branchiopoda) of South Korea with seven new records for the Korean Peninsula // Journal of Species Research. Vol.6. P.227-246.

Kotov A.A., Sinev A.Yu., Glagolev S.M., Smirnov N.N. 2010. [Water fleas (Cladocera)] // V.R. Alexeev \& S.Ya. Tsalolokhin (eds.). Opredelitel' zooplanktona i zoobentosa presnykh vod Evropeyskoy Rossii. Moscow: KMK Sci. Press. P.151-276 [in Russian].

Kotov A.A., Sinev A.Yu., Korovchinsky N.M., Smirnov N.N., Bekker E.I., Sheveleva N.G. 2011b. [Cladocera (Crustacea, Branchiopoda) of the Zeya basin (Amurskaya Area, Russian Federation). 1. New taxa for fauna of Russia] // Zoologichesky Zhurnal. Vol.90. P.131-142 [in Russian].

Kotov A.A., Van Damme K., Bekker E.I., Siboualipha S., SilvaBriano M., Adabache Ortiz A., Galván de la Rosa R., Sanoamuang L. 2013. Cladocera (Crustacea: Branchiopoda) of Vientiane province and municipality, Laos // Journal of Limnology. Vol.72. No.S2. P.81-108.

Krajíček M., Fott J., Miracle M.R., Ventura M., Sommaruga R., Kirschner P., Černý M. 2016. The genus Cyclops (Copepoda, Cyclopoida) in Europe // Zoologica Scripta. Vol.45. P.671682.

Mayor T.Y., Galimova Y.A., Sheveleva N.G., Sukhanova L.V., Kirilchik S.V. 2017. Molecular phylogenetic analysis of Diacyclops and Acanthocyclops (Copepoda: Cyclopoida) from Lake Baikal based on COI gene // Russian Journal of Genetics. Vol.53. No.2. P.252-258.

Manujlova E.F. 1964. [The cladocerans of fauna of the USSR] // Opredeliteli po faune SSSR. Vyp.88. P.1-327 [in Russian]

Markovtsev V.G. 1979. [Nutrition and food relations of the fish of the subfamily Cultrinae of the southern part of the Khanka Lake. PhD Thesis]. Vladivostok: Pacifcal Russian Research Institute of Fisheries and Oceanography. 169 pp. [In Russian]

Mikulich L.V. 1948. [The experience of quantitative accounting of benthos and plankton of the part of the Amur River and some floodplain water bodies] // Izvestiya Tikhookeanskogo NII Rybnogo Khozyaistva i Okeanografii. P.139-164 [in Russian].

Neretina A.N., Garibian P.G., Sinev A.Y., Kotov A.A. 2018. Diversity of the subgenus Disparalona (Mixopleuroxus) Hudec, 2010 (Crustacea: Cladocera) in the New and Old World // Journal of Natural History. Vol.52. No.3-4. P.155-205.

Nikolsky G.V. 1956. [Fishes of Amur River basin. Results of Amur ichthyological expedition of 1944-1949]. Moskva: Izdatel'stvo Akademii Nauk SSR. 551 pp. [In Russian]

Nikonov V.I. 1970. [Natural landscapes. Questions of geography of the Amur region. Lower Amur Region]. Khabarovsk: Nauka. P.167-174 [in Russian].

Novichkova A.A., Chertoprud E.S. 2017. Cladocera and Copepoda of Shokalsky Island: new data from Northwest Siberia // Journal of Natural History. Vol.51. No.29-30. P.1781-1793. 
Popova E.V., Petrusek A., Koøínek V., Mergeay J., Bekker E.I., Karabanov D.P., Galimov Y.R., Neretina T.V., Taylor D.J., Kotov A.A. 2016. Revision of the Old World Daphnia (Ctenodaphnia) similis group (Cladocera: Daphniidae) // Zootaxa. Vol.4161. P.1-40.

Rocha-Olivares A., Fleeger J.W., Foltz D.W. 2001. Decoupling of molecular and morphological evolution in deep lineages of a meiobenthic harpacticoid copepod // Molecular Biology and Evolution. Vol.18. P.1088-1102.

Rylov V.M. 1932. [Scientific results of the Far Eastern hydrofaunistic expedition of the Zoological Museum in 1927. Part 4. Freshwater Eucopepoda of the Ussuri region (Crustacea)] // Trudy Zool. Inst. AN SSSR. Vol.1. No.2. P.243-280 [in Russian].

Rylov V.M. 1948. [Cyclopoida of the fresh-water] // Fauna SSSR. Crustacea. Vol.3. No.3. P.1-321 [in Russian].

Schizas N.V., Street G.T., Coull B.C., Chandler G.T., Quattro J.M. 1999. Molecular population structure of the marine benthic copepod Microarthridion littorale along the southeastern and Gulf coasts of the USA // Marine Biology. Vol.135. P.399405.

Sinev A.Yu. 1997. Review of the affinis-group of Alona Baird, 1843, with the description of a new species from Australia (Anomopoda Chydoridae) // Arthropoda Selecta. Vol.6. No.3 4. P.47-58.

Sinev A.Y. 2009. Discrimination between two sibling species of Acroperus (Baird, 1843) from the Palearctic (Cladocera: Anomopoda: Chydoridae) // Zootaxa. Vol.2176. P.1-21.

Sinev A.Y. 2014. A comparative morphological analysis of four species of Camptocercus Baird, 1843 (Cladocera: Anomiopoda: Chydoridae) // Zootaxa. Vol.3895. P.183-207.

Sinev A.Y., Korovchinsky N.M. 2013. Cladocera (Crustacea: Branchiopoda) of Cat Tien National Park, South Vietnam // Journal of Limnology. Vol.72. No.S2. P.125-141.

Sinev A.Yu., Sanoamuang L. 2013. Notes on Pleuroxus (Picripleuroxus) quasidenticulatus (Smirnov, 1996) (Cladocera: Anomopoda: Chydoridae) from South-East Asia and the Eas of Russia // Invertebrate Zoology. Vol.10. No.2. P.269-280.

Smirnov N.N. 1971. [Chydoridae of the world fauna] // Fauna SSSR. Rakoobraznie. Vol.1. No.2. P.1-531 [in Russian].

Smirnov N.N. 1998. A revision of the genus Camptocercus (Anomopoda, Chydoridae, Aloninae) // Hydrobiologia. Vol.386. P.63-83.
Smirnov N.N., Kotov A.A. 2018. On morphological radiation of Cladocera (Crustacea) // Invertebrate Zoology. Vol.15. No.3. P.231-248.

Smirnov N.N., Sheveleva N.G. 2010. Chydorus irinae sp. n. (Anomopoda, Chydoridae, Chydorinae) from the Tom' River (the Amur basin, Russia) // Zoologichesky Zhurnal. Vol.89. P.635638.

Smirnov S.S. 1929. Beiträge zur Copepodenfauna Ostasiens // Zoologischer Anzeiger. Bd.81. H.1/2. S.317-329.

Streletskaya E.A. 1975a. [List of Rotifera, Cladocera and Copepoda of the Kolyma and Anadyr rivers basins] // V.L. Kontrimavichus (ed.). Gidrobiologicheskiye issledovaniya vnutrennikh vodoemov Severo-Vostoka SSSR. Vladivostok: Dalnevostochniy Nauchniy Tsentr AS SSSR. P.32-59 [in Russian].

Streletskaya E.A. 1975b. [On the question of the systematic position of some freshwater crustaceans in the Kolyma River ba$\sin ]$ // V.L. Kontrimavichus (ed.). Gidrobiologicheskiye issledovaniya vnutrennikh vodoemov Severo-Vostoka SSSR. Vladivostok: Dalnevostochniy Nauchniy Tsentr AS SSSR. P.60138 [in Russian].

Streletskaya E.A. 2010. Review of the fauna of Rotatoria, Cladocera, and Copepoda of the basin of the Anadyr' River // Contemporary Problems of Ecology. Vol.3. No.4. P.469-480.

Uéno M. 1939. Manchurian fresh-water Cladocera // Annotationes Zoologicae Japonenses. Vol.18. P.219-231.

Uéno M. 1940. [Plankton of the four large lakes of Manchoukuo] // T. Kawamura (ed.). Report of the limnological survey of Kwantung and Manchoukuo. Kyoto. P.552-568 [in Japanese].

Vshivkova T.C., Nikitina I.A. 2010. [The first information about the fauna of freshwater invertebrate from wetlands "Bolon"] // IX Dalnevostochnaya Konferentsiya po zapovednomu delu, Vladivostok, 20-22 oktiabrya 2010. Vladivostok: Dal'nauka. P.116-125 [in Russian].

Xu S., Hebert P.D.N., Kotov A.A., Cristescu M.E. 2009. The noncosmopolitanism paradigm of freshwater zooplankton: insights from the global phylogeography of the predatory cladoceran Polyphemus pediculus (Crustacea, Onychopoda) // Molecular Ecology. Vol.18. No.24. P.5161-5179.

Yavorskaya N.M. 2018. [Zooplankton] // V.T. Tagirova \& R.S. Andronova R.S. (eds.). Dalnevostochnaya cherepakha Ozera Gassi. Khabarovsk: Khabarovskaya Kraevaya Tipografiya. 94 p. [In Russian]

Responsible editor V.A. Spiridonov 